\title{
EFFECT OF MICRONUTRIENTS-ENRICHED FERTILIZERS ON BASAL STEM ROT DISEASE INCIDENCE AND SEVERITY ON OIL PALM (ELAEIS GUINEENSIS JACQ.) SEEDLINGS
}

\author{
${ }^{1}$ Fabien Fonguimgo Tengoua, ${ }^{1,3}$ Mohamed M. Hanafi, \\ ${ }^{2}$ A.S. Idris, ${ }^{4}$ Kadir Jugah, ${ }^{1}$ Jamaludin Nurul Mayziatul Azwa, \\ ${ }^{1,5}$ Mohidin Hasmah and ${ }^{6}$ Syed Rastan Syed-Omar \\ ${ }^{1}$ Laboratory of Plantation Crops, Institute of Tropical Agriculture, \\ Universiti Putra Malaysia, 43400 Serdang, Selangor, Malaysia \\ ${ }^{2}$ Ganoderma and Disease Research of Oil Palm (GanoDROP) Unit, \\ Biological Research Division, Malaysian Palm Oil Board (MPOB), 6, \\ Persiaran Institusi, Bandar Baru Bangi, 43000 Kajang, Selangor, Malaysia \\ ${ }^{3}$ Department of Land Management, Faculty of Agriculture, \\ Universiti Putra Malaysia, 43400 Serdang, Selangor, Malaysia \\ ${ }^{4}$ Department of Plant Protection, Faculty of Agriculture, \\ Universiti Putra Malaysia, 43400 Serdang, Selangor, Malaysia \\ ${ }^{5}$ Faculty of Plantation and Agrotechnology, \\ Universiti Teknologi MARA, 94300 Kota Samarahan, Sarawak \\ ${ }^{6}$ DIVERSATECH (M) SDN. BHD, 27-2-2B, Jln Medan PB 28, \\ Seksyen 9, 43650 Pusat Bandar Baru Bangi, Selangor, Malaysia
}

Received 2014-10-10; Revised 2014-11-01; Accepted 2014-11-24

\begin{abstract}
Basal stem rot caused by Ganoderma boninense constitutes a serious threat to oil palm industry in Southeast Asia, especially in Malaysia and Indonesia and in Papua New Guinea and Pacific Islands. It is also expanding in some oil palm growing countries in Latin America and Africa and will soon become a worldwide concern to oil palm cultivation. To date, none of the various control measures developed and tested to control the disease since many decade gives entire satisfaction. An experiment was carried out to see whether incorporation of micronutrients, Copper $(\mathrm{Cu})$, Boron (B) and Manganese (Mn) could reduce the incidence and severity of this disease on oil palm seedlings inoculated with $G$. boninense. The concentrations tested were $2 \mathrm{mg} \mathrm{B} / \mathrm{kg}$ of soil, $2 \mathrm{mg} \mathrm{Cu} / \mathrm{kg}$ of soil and $2 \mathrm{mg} \mathrm{Mn} / \mathrm{kg}$ of soil incorporated into the basic fertilizer NPKMg 14-10-10-2. Treatments were applied in solution for three months before inoculation, followed by soil application for eight months after inoculation. The results showed that although no significant difference was detected among treatments, the double combinations of these micronutrients, $\mathrm{B}+\mathrm{Cu}, \mathrm{B}+\mathrm{Mn}$ and $\mathrm{Cu}+\mathrm{Mn}$, performed better than the single nutrients in reducing the incidence and the severity of BSR, while their triple combination rather increased these pathological parameters. These double combinations could therefore be field-tested for their further integration in oil palm fertilization programme.
\end{abstract}

Keywords: Basal Stem Rot, Ganoderma Boninense, Oil Palm, Boron, Copper, Manganese

Corresponding Author: Fabien Fonguimgo Tengoua, Laboratory of Plantation Crops, Institute of Tropical Agriculture, Universiti Putra Malaysia, 43400 Serdang, Selangor, Malaysia, Tel: +603-8947 4861/+6013 356 5900, Fax: +603-8940 8316 


\section{INTRODUCTION}

Ganoderma Basal Stem Rot (BSR) is the most devastating disease of oil palm (Ariffin et al., 2000; Idris, 2009; Susanto, 2009) and constitutes a permanent threat to oil palm in Southeast Asia (Pilotti, 2005; Utomo et al., 2005). Despite the slow progression of the disease, it can destroy thousands of hectares of oil palm. Serious yield reductions and death of palms due to Ganoderma attacks have been recorded especially in replanted areas, where the disease was endemic in the previous generation. Initially considered a disease of old palms and concentrated in coastal areas on peat soils (Singh, 1991), the BSR disease is now infecting oil palm at all ages starting from the first year of field planting. In Malaysia, a $3.7 \%$ incidence of BSR corresponding to 59,148 ha affected was reported in 2010 (Idris, 2011; Idris et al., 2011). It has spread rapidly to cover all oil palm cultivating areas and all types of soils (Idris, 1999; Khairudin and Tey, 2008), thereby becoming a great concern in Malaysia and all over the world (Turner and Gillbanks, 2003). In Sabah in the Kinabalu estate, about $30 \%$ of second generation under-planted palms were reported to be infected by Ganoderma with in one to two years after planting (Wan, 2007). In Sime Darby plantations, $1.4 \%$ BSR incidence, equivalent to about 580 ha, was recorded in 2007 (Khairudin and Tey, 2008). In Cameroon, losses as high as $53.2 \%$ of dead palms over 25 years old in a first generation plantation was estimated, mainly due to Ganoderma (Tengoua and Bakoume, 2005), while, 6.4\% palm death was recorded in a 10 -year-old replanting when palms were at their peak production age (Tengoua, 2005).

Recent efforts to tackle the problem have been focused on biological control agents, such as Trichoderma (Ilias, 2000; Shamala, 2005; Izzati and Faridah, 2008; Siddiquee et al., 2009), endophytic fungi and endophytic bacteria (Shamala et al., 2011), Gliocladium (Flood and Hasan, 2004), Pseudomonas fluorescens and Bacillus sp (Susanto et al., 2005). The use of a balanced chemical fertilizer, namely N, P and K (Mohd Tayeb and Hamdan, 1999; Mohd Tayeb et al., 2003) and manual application of calcium nitrate (Sariah and Zakaria, 2000; Flood and Hasan, 2004) have also been investigated.

Nutrient addition to soil as fertilizer is known to affect plant resistance/susceptibility to some diseases caused by fungal pathogens (Veresoglou et al., 2013). Despite their direct action on pathogenic agents through their biocidal properties and their indirect action through their involvement in a number of plant defence mechanisms, micronutrients have not been considered in BSR control strategies. Boron (Stangoulis and Graham, 2007), Cu (Evans et al., 2007) and Mn (Thompson and Huber, 2007) are reported to control many plant diseases. Copper, B and Mn are all intimately involved in phenol synthesis in plants and have major effects on host susceptibility to disease (Graham, 1983). This study was initiated to see whether incorporation of single and combined optimum concentrations of these micronutrients in a commonly used compound fertilizer grade NPKMg (14:10:10:2), can reduce BSR incidence and severity on oil palm seedlings.

\section{MATERIALS AND METHODS}

\subsection{Plant and Fungal Materials}

One-month-old commercial Tenera oil palm seedlings $($ dura $\times$ pisifera $)$ were purchased from the Federal Land Development Authority (FELDA) Agricultural Services Sdn. Bhd. Sungai Tekam, Jerantut, Pahang, Malaysia. In the first phase of the experiment, seedlings were supplied for three months with different fertilizer treatments applied in solution. After two weeks acclimatization, kernels were removed to ensure that the response obtained will solely result from fertilizer treatments with minimum influence from endosperm nutrient reserves. Treatments were renewed every week. The composition of different fertilizer treatments used is as follows: $\mathrm{T} 1$ (Control 1, non-inoculated) = Basic fertilizer $(\mathrm{BF})$; $\mathrm{T} 2$ (Control 2, inoculated) $=$ Basic fertilizer $(\mathrm{BF})$; $\mathrm{T} 3=\mathrm{BF}+2 \mathrm{mg} \mathrm{B} / \mathrm{kg}$ of soil; $\mathrm{T} 4=\mathrm{BF}$ $+2 \mathrm{mg} \mathrm{Cu} / \mathrm{kg}$ of soil; $\mathrm{T} 5=\mathrm{BF}+2 \mathrm{mg} \mathrm{Mn} / \mathrm{kg}$ of soil; $\mathrm{T} 6=\mathrm{BF}+2 \mathrm{mg} \mathrm{B} / \mathrm{kg}$ of soil $+2 \mathrm{mg} \mathrm{Cu} / \mathrm{kg}$ of soil; $\mathrm{T} 7$ $=\mathrm{BF}+2 \mathrm{mg} \mathrm{B} / \mathrm{kg}$ of soil $+2 \mathrm{mg} \mathrm{Mn} / \mathrm{kg}$ of soil; $\mathrm{T} 8=$ $\mathrm{BF}+2 \mathrm{mg} \mathrm{Cu} / \mathrm{kg}$ of soil $+2 \mathrm{mg} \mathrm{Mn} / \mathrm{kg}$ of soil; $\mathrm{T} 9=$ $\mathrm{BF}+2 \mathrm{mg} \mathrm{B} / \mathrm{kg}$ of soil $+2 \mathrm{mg} \mathrm{Cu} / \mathrm{kg}$ of soil $+2 \mathrm{mg}$ $\mathrm{Mn} / \mathrm{kg}$ of soil. The Basic Fertilizer (BF) is the commonly used commercial fertilizer NPKMg (14:10:10:2), where $\mathrm{N}$ stands for $\% \mathrm{~N}(14 \%)$, P for $\%$ $\mathrm{P}_{2} \mathrm{O}_{5}(10 \%), \mathrm{K}$ for $\% \mathrm{~K}_{2} \mathrm{O}(10 \%)$ and $\mathrm{Mg}$ for $\% \mathrm{MgO}$ $(2 \%)$. The sources of micronutrients were borax pentahydrate $\left[\mathrm{Na}_{2} \mathrm{~B}_{4} \mathrm{O}_{7} . \quad 5 \mathrm{H}_{2} \mathrm{O} \quad\left(\begin{array}{lll}48 \% & \left.\mathrm{~B}_{2} \mathrm{O}_{3}\right)\end{array}\right]\right.$ for $\mathrm{B}$, copper sulphate pentahydrate $\left[\mathrm{CuSO}_{4} \cdot 5 \mathrm{H}_{2} \mathrm{O} \quad(25 \%\right.$ $\mathrm{Cu})$ for $\mathrm{Cu}$ and manganese sulphate monohydrate $\left[\mathrm{MnSO}_{4} . \mathrm{H}_{2} \mathrm{O}(31.8 \% \mathrm{Mn})\right]$ for $\mathrm{Mn}$.

The pure culture of Ganoderma boninense PER 71 used was supplied by the Ganoderma and Disease Research for 
Oil Palm (GanoDROP) Unit, Biology Division, Malaysian Palm Oil Board (MPOB), Bangi, Malaysia.

\subsection{Inoculum Preparation and Inoculation of Oil Palm Seedlings with G. Boninense}

The Ganoderma Rubber Wood Block (RWB) inoculum was prepared following the general method routinely used by MPOB and described by (Idris, 1999). Briefly, freshly cut RWBs $(6 \times 6 \times 6 \mathrm{~cm})$ were oven-dried at $80^{\circ} \mathrm{C}$ for $48 \mathrm{~h}$ and sterilized at $121^{\circ} \mathrm{C}$ for $30 \mathrm{~min}$. The RWBs were then put in a heat resistant polyethylene bag (one RWB per bag) to which $60 \mathrm{~mL}$ of Malt Extract Agar (MEA) were added, autoclaved at $121^{\circ} \mathrm{C}$ for $30 \mathrm{~min}$ and left to cool over night, with rotation to allow the medium to evenly cover the RBWs before solidification. After cooling, the RWBs were inoculated with a 7 to 10 day-old pure culture of $G$. boninense PER 71. One plate divided into eight fragments was used to inoculate two RWBs, each receiving four fragments of $G$. boninense put on the four lateral surfaces. The inoculated RWBs were kept in the dark at $28^{\circ} \mathrm{C}$ for three months to allow external and internal colonization by $G$. boninense. At the end of three month incubation, prior to inoculation, fully covered RWBs (Fig. 1A and B) were tested on GanodermaSelective Medium (GSM) (Ariffin and Idris, 1992) to confirm the internal colonization. The positive test was confirmed by the development of Ganoderma mycelium from the fragment of wood taken from the centre of split RWBs (Fig. 1C) and by browning of the medium when observed from the bottom of the Petri dish (Fig. 1D).

The inoculation of oil palm seedlings with Ganoderma RWB inoculum (second phase of the experiment) consisted of a sitting technique, whereby the bulb and washed roots of each seedling were firmly put in contact with a RWB inoculum standing on one third of $5 \mathrm{~kg}$ of the Munchong series soil in a polybag $(25 \times 30 \mathrm{~cm})$ and covered with the remaining soil. Soils of the Munchong series are characterized by their low fertility status. For each treatment, two extra seedlings were inoculated and kept aside for eventual replacement. Seedlings of treatments T1 (absolute control) were not inoculated with RWB inoculum but simply transplanted in polybags filled with $5 \mathrm{~kg}$ of soil.

\subsection{Maintenance}

Inoculated seedlings and the control received monthly fertilizer treatments (10 g/plant) with daily watering for eight months. On a weekly basis, the lower surface of the leaves was sprayed with water to wash off red spider mites (Oligonychus sp. and/or Tetranychus piercei). The use of chemicals was minimal so as not to compromise the infection by $G$. boninense (Naher et al., 2012). When extremely needed, insecticides (Rogor 40 (Dimethoate 38.0\% $\mathrm{w} / \mathrm{v}$ ) and Decis (Deltamethrin $1.4 \% \mathrm{w} / \mathrm{v})$ ) were sprayed alternatively to control insect attacks.

\subsection{Assessment of Pathological Parameters}

\subsubsection{External Symptoms}

External symptoms of $G$. boninense infection were recorded every month starting two months after inoculation until the eighth month (end of experiment). These include the total number of leaves; the number of green, yellow and dry leaves; presence or absence of mycelium and/or white button or basidiocarps at the plant base and the disease class. From these data, the Severity of Foliar Symptoms (\%SFS), the Disease Incidence (DI) and the Disease Severity Index (DSI) were assessed. The severity of foliar symptoms for each seedling was calculated by the following formula (Sariah and Zakaria, 2000):

$$
\% S F S=\frac{[(D \times 1)+(Y \times 0.5)]}{T} \times 100
$$

where, D is the number of desiccated (dry or dead) leaves, $\mathrm{Y}$ the number of yellow, chlorotic or wilted leaves, $\mathrm{T}$ the total number of leaves, the numerical value 1 represents the index for desiccated leaves and 0.5 the index for chlorotic leaves.

The Disease Incidence (DI) for each treatment in each replication and the Area Under Disease Progress Curve (AUDPC) for the severity of foliar symptoms and disease incidence were assessed following (Campbell and Madden, 1990):

$$
\begin{gathered}
D I(\%)=\frac{\text { Number of seedlings infected }}{\text { Total number of seedlings assessed }} \times 100 \\
A U D P C=\sum_{i}^{n-1}\left(\frac{Y_{i}+Y_{i+1}}{2}\right)\left(t_{i+1}-t_{i}\right)
\end{gathered}
$$

where, $\mathrm{n}$ is the number of assessment time, $\mathrm{Y}$ the disease incidence or the percentage severity of foliar symptoms and $\mathrm{t}$ the observation time. The AUDPC indicates the amount of disease developed in each treatment over 
time. The lower the AUDPC value of a treatment, the more effective the treatment in reducing the disease. The percentage of Disease Reduction (DR) for each treatment was deduced from the AUDPC by the formula:

$$
D R(\%)=\frac{A U D P C \text { control }- \text { AUDPCtreatment }}{A U D P C \text { control }} \times 100
$$

\section{The control here is $\mathrm{T} 2$.}

The Epidemic Rate (ER) for each treatment was calculated using the formula $\mathrm{y}=\ln \left[\frac{1}{(1-x)}\right]$ applied to a monocyclic or monomolecular epidemic model (Campbell and Madden, 1990) appropriate for soil borne fungi like $G$. boninense, where y is the amount of disease at a given time and $\mathrm{x}$ the disease incidence in proportion, not in percentage. The value of the Epidemic Rate (ER) corresponds to the slope of the straight line $\mathrm{y}=$ $\ln \left[\frac{1}{(1-x)}\right]$ plotted against $t$, the observation time.

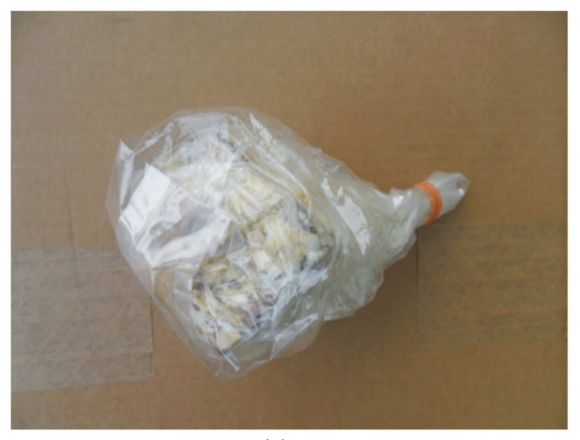

(a)

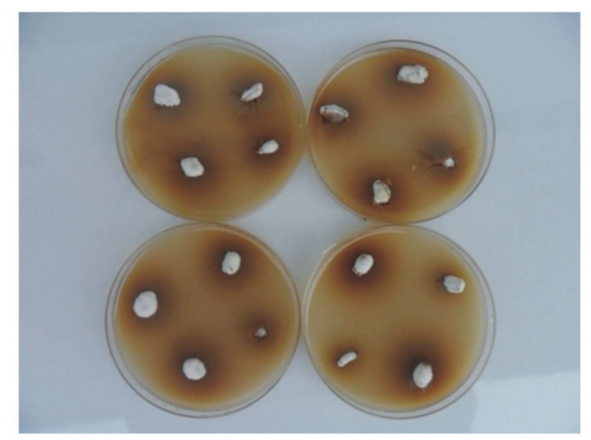

(c)
The Disease Severity Index (DSI) was calculated according to (Ilias, 2000; Abdullah et al., 2003) as follows:

$$
D S I=\frac{\sum(A \times B)}{\sum B \times 4} \times 100
$$

where, $\mathrm{A}$ is the disease class $(0,1,2,3$, or 4$), \mathrm{B}$ the number of seedlings showing that disease class per treatment, $\sum B$ the total number of seedlings assessed and 4 the highest rating or disease class value. Since the basidiocarps (fruiting bodies) do not always develop in all Ganoderma screening tests (Sariah et al., 1994; Kandan et al., 2009), the description of disease scales (classes) (Ilias, 2000; Abdullah et al., 2003; Breton et al., 2006) that emphasized on the presence of a fruiting body as an important characteristic in classifying Ganoderma symptoms was modified to address this natural fact (Table 1, Fig. 2 and 3). These modifications rely on the observation that most of the infected plants passed across all the scales and died without any basidiocarp (Fig. 4A).

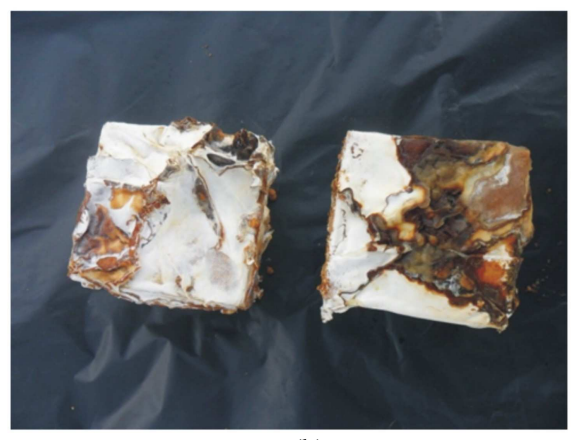

(b)

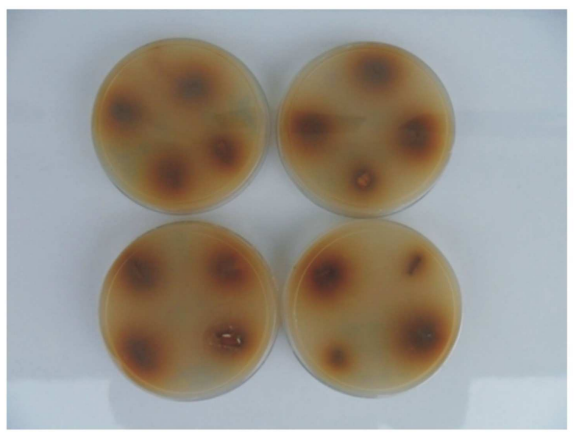

(d)

Fig. 1. Three-month-old fully colonized Rubber Wood Block (RWB) by G. boninense PER 71 in heat resistant plastic (A), removed from the plastic for GSM testing (B); Note: The development of $G$. boninense from the RWB fragments (C) and the brown coloration of the medium observed from the inverted plates (D) at the 5 th day of incubation at $28^{\circ} \mathrm{C}$ in the darkness 
Fabien Fonguimgo Tengoua et al. / American Journal of Applied Sciences 11 (10): 1841-1859, 2014
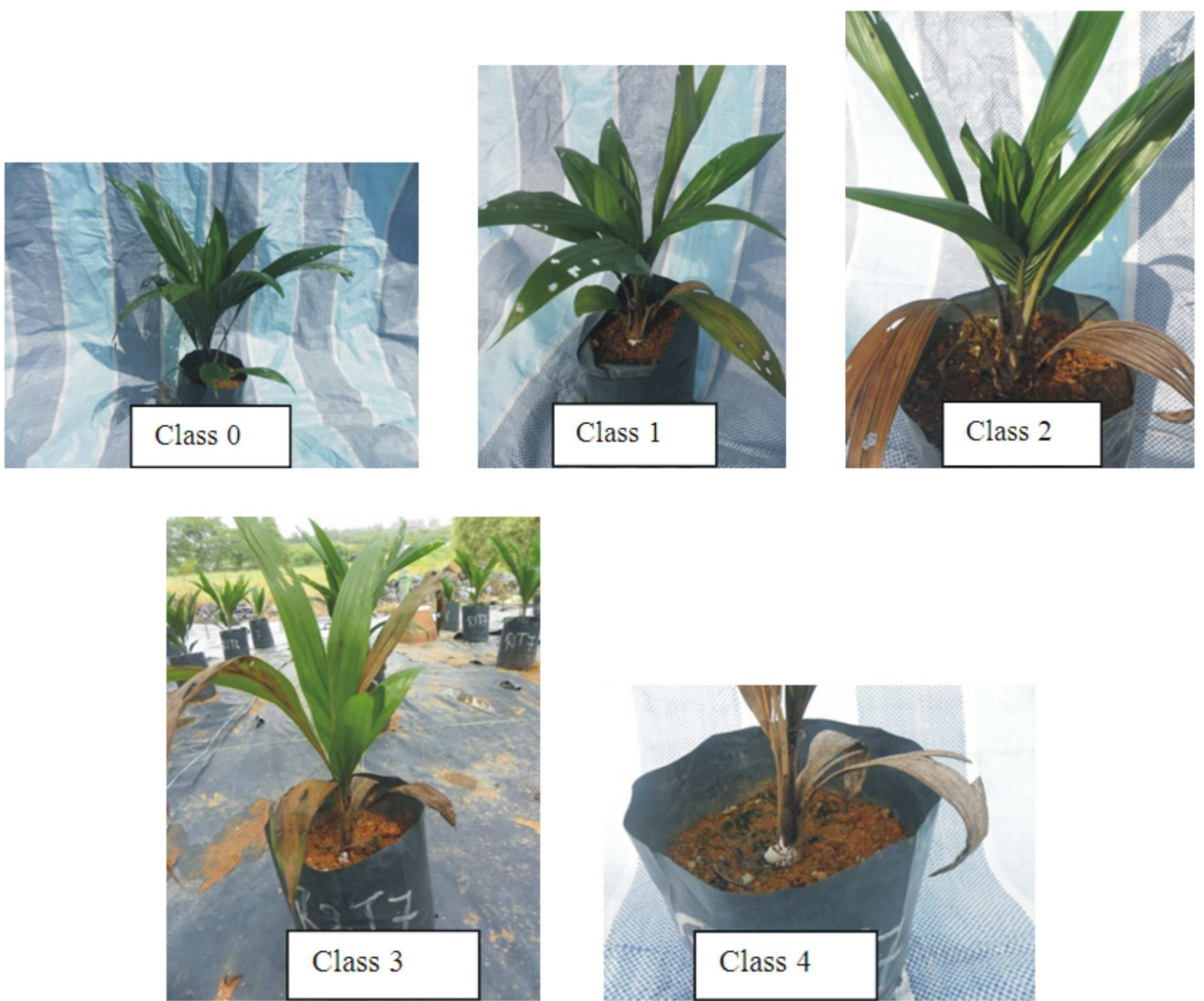

Fig. 2. Illustration of different classes (0-4) of $G$. boninense external symptoms on oil palm seedlings at an early growth stage (2-5 months after inoculation)
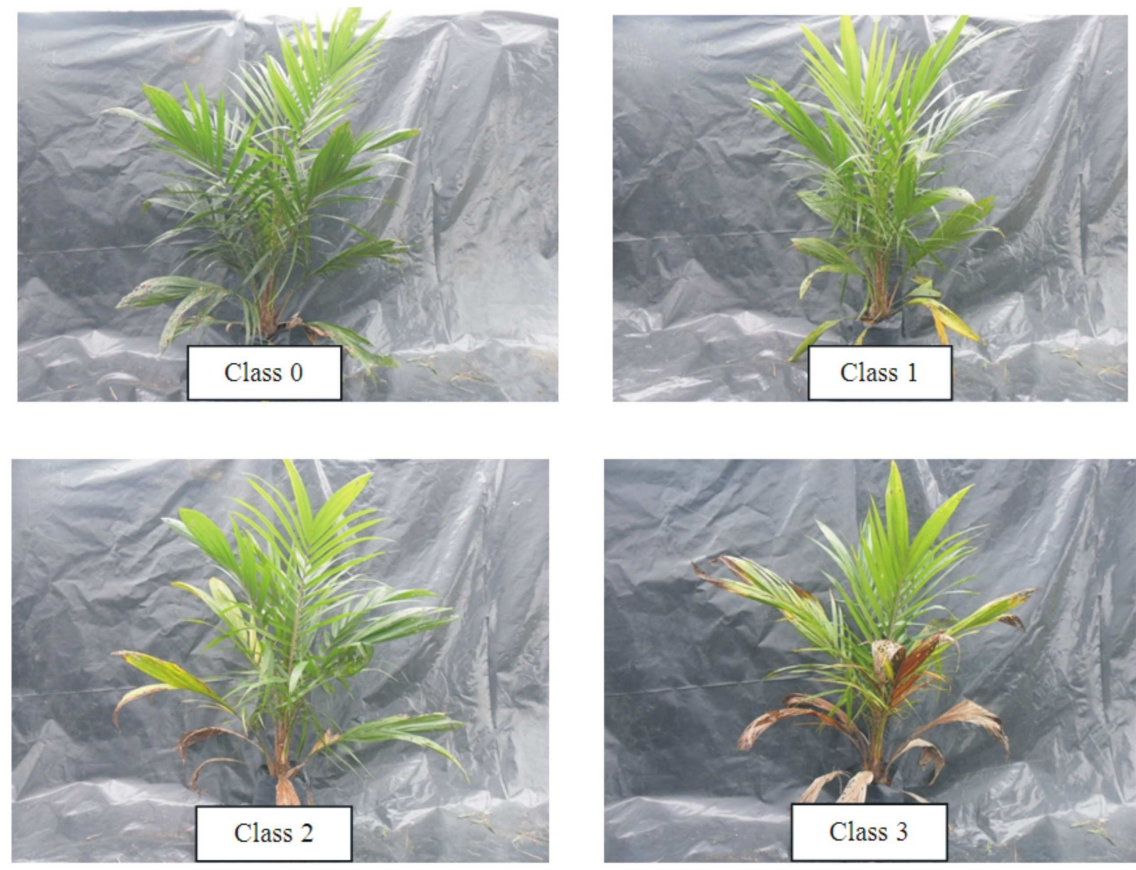
Fabien Fonguimgo Tengoua et al. / American Journal of Applied Sciences 11 (10): 1841-1859, 2014

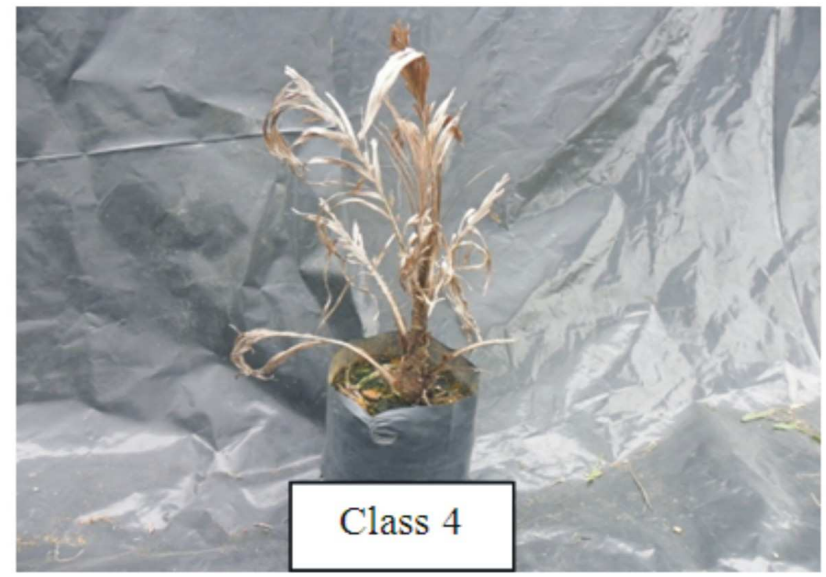

Fig. 3. Illustration of different classes of $G$. boninense external symptoms on oil palm seedlings at an advanced growth stage (8 months after inoculation)

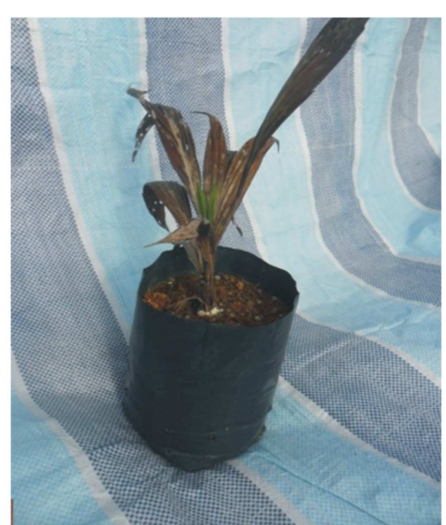

(a)

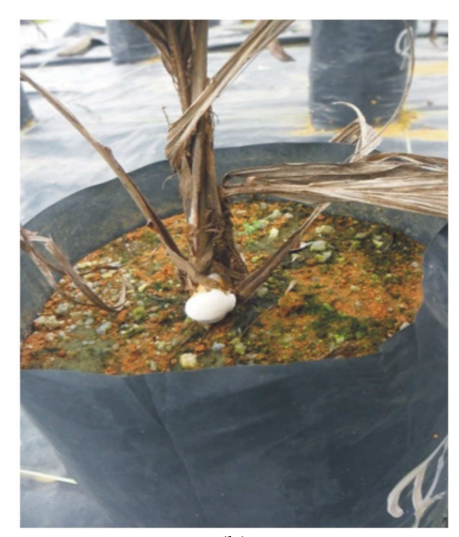

(b)

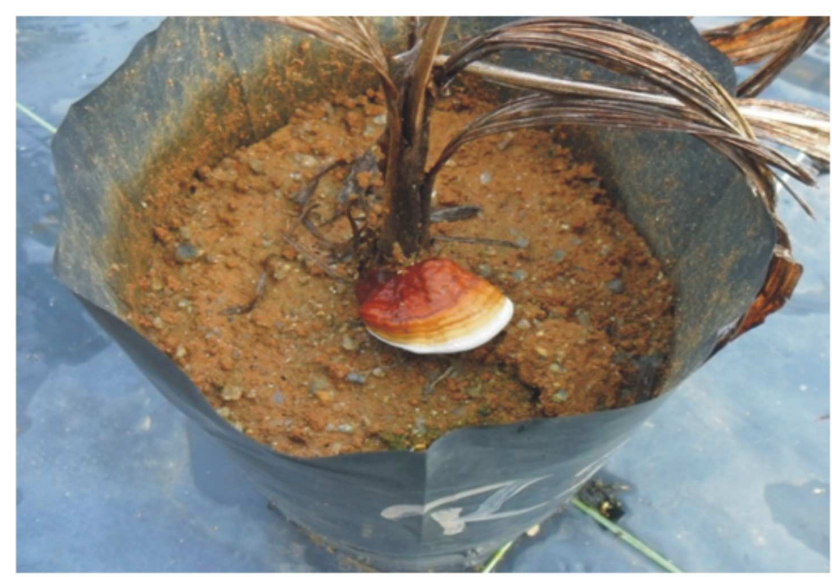

(c)

Fig. 4. Development of G. boninense white mycelium (A), white button (B) and formation of a full basidiocarp (C) on dead oil palm seedlings 
Table 1. Description of disease classes of Ganoderma external symptoms

\begin{tabular}{ll}
\hline Disease class & Symptom description \\
\hline 0 & Healthy plant with green leaves without the appearance of fungal mycelium on any part of the plant \\
1 & Appearance of white fungal mass on any part of the plant, with or without chlorotic leaves \\
& Chlorotic and/or necrotic leaves (1-3), with or without the appearance of basidiocarps on any \\
& part of the plant \\
Chlorotic and/or necrotic leaves $(\square 3), \geq 50 \%$ drying up or necrotic, with or without the formation of \\
basidiocarps on any part of the plant \\
Total necrosis, whole plant dry or dead, with or without the formation of well-developed
\end{tabular}

Source: Adapted from Ilias (2000; Abdullah et al., 2003; Breton et al., 2006)

In all the cases observed, the white buttons, initiation or primordia of fruiting body development, appeared when the plants were already dead (class 4) (Fig. 4B) and progressed until the formation of a full basidiocarp on the dead plant (Fig. 4C).

\subsubsection{Internal Symptoms}

At the end of experiment, surviving seedlings were assessed for BSR internal symptoms. Number of rotted primary roots was recorded and the bulb was longitudinally dissected to observe and measure the extent of rotted area using a grid. Both the rotted and the total areas were measured to confidently transform in percentage the results expressed in surface unit and classify following the scale adapted from Nur Sabrina et al. (2012; Breton et al., 2006) (Table 2 and Fig. 5). The percentage of infected bulb area was calculated as followed:

$$
\% \text { infected bulb area }(\% I B A)=\frac{\text { Infected bulb area }(I B A)}{\text { Total bulb area }(T B A)} \times 100
$$

After determining the disease class from the \%IBA, the Disease Severity Index (DSI) for internal symptoms, more specifically for bulb symptoms or bulb decay (DSIB) was then calculated as previously described for external symptoms:

$$
\operatorname{DSIB}(\text { Internal })=\frac{\sum\left(A^{\prime} \times B^{\prime}\right)}{\sum B^{\prime} \times 4} \times 100
$$

where, $\mathrm{A}^{\prime}$ is the rating number or class, $\mathrm{B}$ ' the number of seedlings in that rating number, $\sum B^{\prime}$ the total number of seedlings assessed and 4 the highest rating.

Similarly, the Disease Severity Index for Root infection (DSIR) was calculated according to the formula:

$$
\operatorname{DSIR}=\frac{\sum\left(A^{\prime \prime} \times B^{\prime \prime}\right)}{\sum B^{\prime \prime} \times 4} \times 100
$$

where, $A$ " is the rating number, B" the number of seedlings in that rating, $\sum B^{\prime \prime}$ the total number of seedlings assessed and 4 the highest rating. The classification or the rating of Ganoderma infection in the roots of oil palm seedlings was adapted from Nur Sabrina et al. (2012; Breton et al., 2006) as follows: Class $0=$ healthy, no root infection; class $1=$ Less than $25 \%$ of roots infected; class $2=25$ to $50 \%$ of roots infected; class $3=51$ to $75 \%$ of roots infected; and class $4=$ more than $75 \%$ of roots infected.

\subsection{Experimental Design and Data Analysis}

The experiment was laid out in a Randomized Complete Block Design (RCBD) with nine treatments and four replicates (blocks). Each treatment consisted of four oil palm seedlings (experimental unit). Data were analyzed by ANOVA using SAS 9.2. The disease incidence and disease severity of foliar symptoms were square root-transformed to reduce the standard error. Means comparison was performed by Duncan's Multiple Range Test (DMRT) at the 0.05 significance level.

\section{RESULTS AND DISCUSSION}

The pathological data (disease incidence and severity, percentage of dead seedlings) were recorded every month. For better visibility and clarity reasons, the results presented and discussed in this study concern the data of two, four, six and eight months after inoculation, i.e., two-month intervals.

\subsection{Severity of Foliar Symptoms}

Two months after inoculation, treatment T9 had the most severe foliar symptoms (13.15\%) and was significantly different from the other treatments (Fig. 6). The inoculated control (T2) and the $\mathrm{B}+\mathrm{Cu}$ treatment (T6) had the lowest Severity of Foliar Symptoms (SFS) 
$(0.39 \%)$. No foliar symptom was observed on treatments $\mathrm{T} 4(\mathrm{Cu})$ and $\mathrm{T} 8(\mathrm{Cu}+\mathrm{Mn})$ at this stage, indicative of their ability to delay disease development. As expected, no sign of Ganoderma could be seen on T1 since it was not inoculated. Four months later, Ganoderma infection was not significantly different with all treatments but varied from SFS $23.6 \%$ with B + Mn (T7) to $34.85 \%$ with $\mathrm{B}$ alone (T3). At six months, treatments were not statistically different in SFS but B + Mn (T7) had the lowest SFS (58.10\%) and Mn alone (T5) the highest $(66.43 \%)$. The same trend was observed at eight months where T7 registered $67.69 \%$ SFS and the triple combination (T9) the highest SFS $(87.71 \%)$. It is interesting to notice that throughout the experiment, the highest SFS was recorded either on T9 or on any treatment with a single micronutrient, while the lowest SFS was observed mostly on treatments supplemented with a combination of two micronutrients. This denotes the superiority of a double combination of micronutrients over the single and triple combination in reducing the SFS on inoculated oil palm seedlings.

\subsection{Disease Severity Index for Foliar Symptoms}

There were significant differences among treatments for the disease severity index for foliar symptoms (DSIF) (Table 3). At two months, seedlings receiving $\mathrm{B}, \mathrm{Cu}$ and Mn (T9) were severely infected by $G$. boninense compared to other treatments with index as high as 14.06. Treatments $\mathrm{Cu}(\mathrm{T} 4), \mathrm{Mn}(\mathrm{T} 5)$ and $\mathrm{Cu}+\mathrm{Mn}$ (T8) had a DSIF $=0$, showing they were not yet infected. From four months on, despite the increasing DSIF, the statistical analysis did not detect any significant difference among treatments; however, T9 remained the most severe throughout while, T6, T8 and T7 were less severe at four, six and eight months, respectively, supporting once more the superiority of double combinations of $\mathrm{B}, \mathrm{Cu}$ and $\mathrm{Mn}$ over the triple combination in reducing Ganoderma infection.

\subsection{Disease Incidence}

Although there were no significant differences in Disease Incidence (DI) (Fig. 7), treatment T9 had the highest DI (18.7\%) as early as two months after inoculation and was the most severely infected from the sixth month till the end of the experiment. With the exception of treatments T2, T3, T6 and T7 with the same incidence of $6.25 \%$, treatments $\mathrm{T} 4$, T5 and T8 were not yet infected at two months. Four months after inoculation, T2 (NPK 14:10:10:2 without micronutrients) had the highest disease incidence $(56.25 \%)$ compared to the treatments supplemented with $\mathrm{B}, \mathrm{Cu}$ and $\mathrm{Mn}$ although none were significantly different. At eight months after inoculation, while T9 and T6 had the highest DI (87.50\%), T2, T7 and T8 had the lowest DI $(68.75 \%)$. This could indicate that the fertilizer formulation NPKMg 14:10:10:2 has the same capacity to reduce Ganoderma incidence as its $\mathrm{B}+\mathrm{Mn}$ and $\mathrm{Cu}$ + Mn-supplemented formulations, whereas, the NPKMg 14:10:10:2 supplemented with either B, Cu and $\mathrm{Mn}$ alone, or $\mathrm{B}+\mathrm{Cu}$, or with the combination of the three micronutrients has low potential to reduce Ganoderma incidence.

\subsection{Area under Disease Progress Curve, Disease Reduction and Epidemic Rate}

Treatment T7, a combination of $\mathrm{B}+\mathrm{Mn}$, had the lowest Area Under the Disease Progress Curve (AUDPC) of 236 unit $^{2}$, with the corresponding highest disease reduction of $9.63 \%$ and the lowest epidemic rate of 0.19 unit month ${ }^{-1}$ (Table 4). This indicates the effectiveness of B added together with Mn to the basic fertilizer in reducing the severity of foliar symptoms of G. boninense on oil palm seedlings. Surprisingly, the inoculated control T2 had an AUDPC lower than some treatments with an Epidemic Rate (ER) of 0.21 unit month $^{-1}$ and close to the most effective treatment $\mathrm{T} 7$. Treatments T3, T5 and T9 with higher AUDPCs than T2, had negative Disease Reductions (DR) of -7.67, 4.58 and $-15.15 \%$, respectively. This indicates that the addition of $\mathrm{B}, \mathrm{Mn}$, or $\mathrm{B}+\mathrm{Cu}+\mathrm{Mn}$ to NPK fertilizer increased the severity of foliar symptoms of $G$. boninense in oil palm seedlings. The negative effects of these nutrients are more intense with the triple combination which had an AUDPC of 300.70 unit $^{2}$, increased severity of foliar symptoms by $15.51 \%$ and the highest epidemic rate of 0.32 unit month ${ }^{-1}$.

As far as the disease incidence is concerned, $\mathrm{Cu}+$ Mn (T8) had the lowest AUDPC (237.5 unit ${ }^{2}$ ) which could mean that the combination of $\mathrm{Cu}+\mathrm{Mn}$ with the basic fertilizer may be more effective than other treatments in reducing Ganoderma incidence in oil palm seedlings; however the treatment $\mathrm{T} 9$, with $\mathrm{B}+\mathrm{Cu}+\mathrm{Mn}$ had the highest AUDPC (356.25 unit ${ }^{2}$ ) meaning that the triple combination not only failed to reduce but rather increased the incidence of disease by $14 \%$ which was the highest rate of 0.36 unit month $^{-1}$. Like treatment $\mathrm{T} 9, \mathrm{~T} 5$ also had a higher AUDPC (318.75) than the control and increased disease incidence by $2 \%$. On the other hand, B (treatment T3), which increased the severity of foliar 
symptoms, decreased disease incidence by $8 \%$. Combination of B $+\mathrm{Mn}$ (T7), with the second lowest AUDPC (262.45 unit ${ }^{2}$ ) had the second highest DR $(16.02 \%)$ suggesting that the double combination of B + $\mathrm{Mn}$ with NPK fertilizer may reduce Ganoderma incidence as well as $\mathrm{Cu}+\mathrm{Mn}$.

In general, all of the double combinations, $\mathrm{B}+\mathrm{Cu}$ (T6), B + Mn (T7) and $\mathrm{Cu}+\mathrm{Mn}$ (T8) reduced both Ganoderma severity of foliar symptom and Ganoderma incidence. Manganese alone and the triple combination of the selected micronutrients detrimentally increased Ganoderma incidence and severity. Copper alone reduced to a slight extent these two pathological parameters, while B alone has a variable effect to reduce Ganoderma incidence but increases its severity. The positive effect of $\mathrm{Cu}$ on Ganoderma reduction obtained in the current study is consistent with that of Nur Sabrina et al. (2012) who found that $\mathrm{Cu}$ supplementation reduced Ganoderma incidence by $51.52 \%$ and its severity by $60.00 \%$; however, the disease reduction by $\mathrm{Cu}$ in our study (6\% disease incidence and $1.06 \%$ disease severity) was not significant and low compared to these authors report. The discrepancy observed could be explained by two main reasons. Firstly, they inoculated six-month-old seedlings with Ganoderma after pre-treatment with fertilizers for three months. In contrast, in the present study, the oil palm seedlings were pre-treated for the same three months but starting at one-month-old and inoculated at four months. In this case, the seedlings might not have developed a strong enough defence system to withstand Ganoderma. Secondly, the present study used basic fertilizer NPKMg 14:10:10:2 whereas, Nur Sabrina et al. (2012) used NPK 15:6:4, i.e., with high $\mathrm{N}$, low $\mathrm{P}$ and very low $\mathrm{K}$. According to Graham (1983), excess $\mathrm{N}$ may encourage fungal pathogens, especially if $\mathrm{P}$ or $\mathrm{K}$ is low. Since a high $\mathrm{N}$ - and low $\mathrm{K}$ - fertilizer has been shown to increase Ganoderma incidence and severity as opposed to a low $\mathrm{N}$ - and high K-fertilizer (Mohd Tayeb et al., 2003), fertilizer used in this study may have contributed to the reduction of Ganoderma incidence and severity to mask the beneficial effects of micronutrients in this study. This is supported by the AUDPCs of some treatments that were higher than the inoculated control (T2) making it appear effective in disease reduction. The positive lesson to learn from this fact may be that in Ganoderma screening tests care should be taken to ensure that the formulation of basic fertilizer will not compromise the expected results, more specifically high $\mathrm{N}$ - and low $\mathrm{K}$ - or low $\mathrm{P}$ fertilizer should be preferred in such tests.

\subsection{Percentage of Dead Seedlings}

As early as two months after inoculation (Table 5), the $\mathrm{B}+\mathrm{Cu}+\mathrm{Mn}$ Treatment (T9) already had $12.50 \%$ of dead seedlings and T2 only $6.25 \%$ due to Ganoderma infection. All of the inoculated seedlings were still alive in other treatments. Four months after inoculation, the percentage of dead seedlings increased in all treatments with $\mathrm{T} 9$ having the highest percent $(31.25 \%)$. As the observation time proceeded, the number of dead seedlings increased with a little variation in the ranking without statistical differences until the end of the experiment (eight months after inoculation). At that time, the number of dead seedlings reached the highest level $(81.25 \%)$ in T9. The lowest percentage was recorded with B + Mn (T7) at $56.25 \%$, followed by $\mathrm{Cu}+\mathrm{Mn}$ (T8) at $62.50 \%$. For this pathological parameter, the trend toward the favourable effect of the double combination of the selected micronutrients in delaying BSR infection was still observed, even though T6 (combination of $\mathrm{B}+\mathrm{Cu}$ ) had $75 \%$ dead seedlings at the end of the experiment.
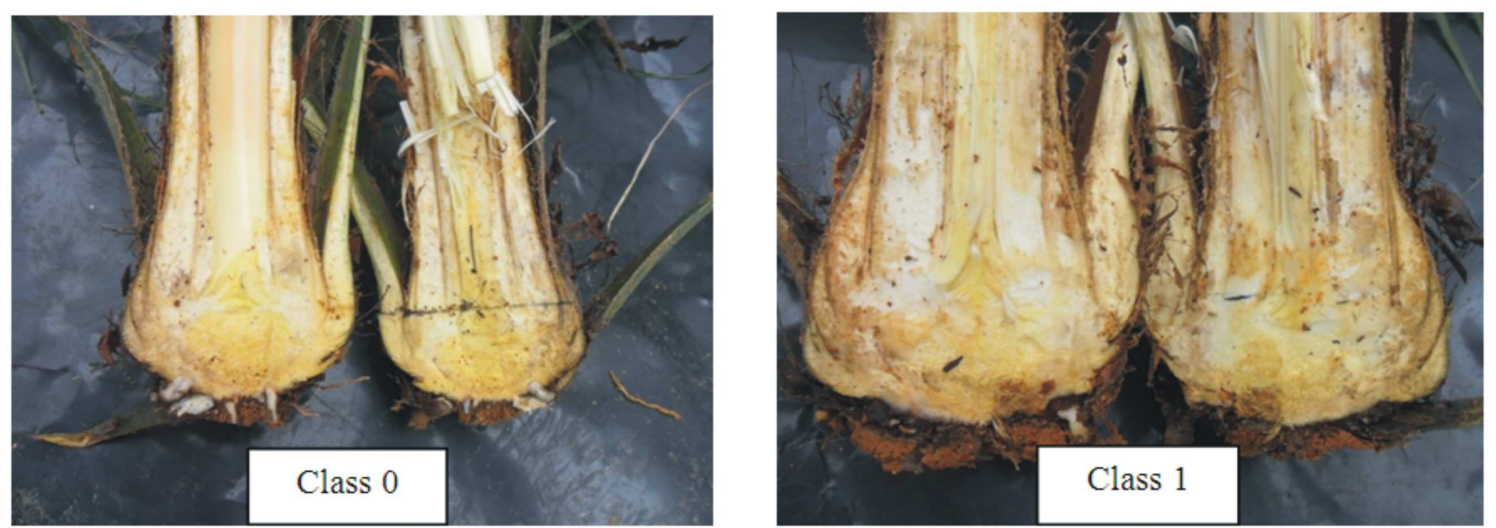
Fabien Fonguimgo Tengoua et al. / American Journal of Applied Sciences 11 (10): 1841-1859, 2014
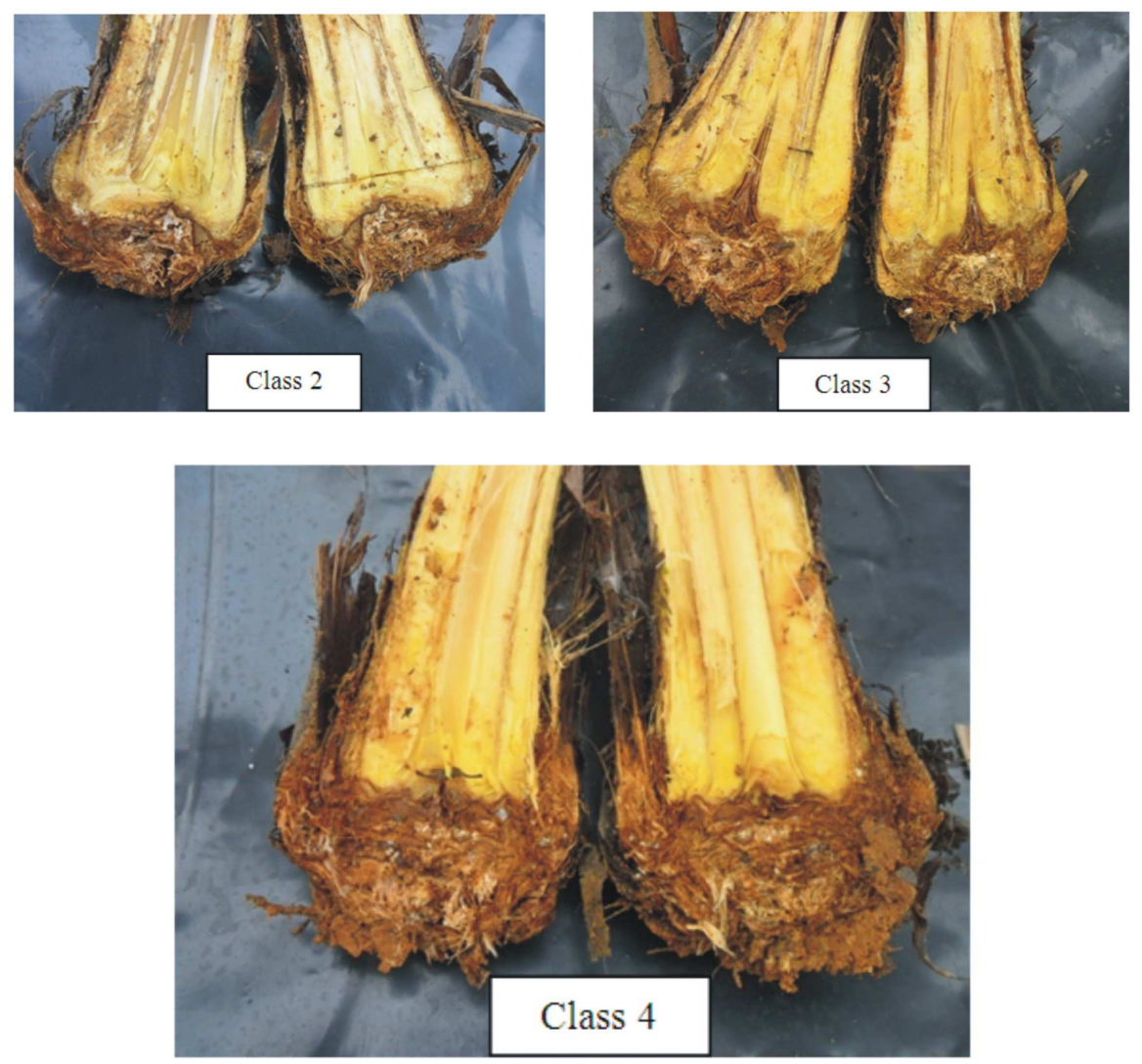

Fig. 5. Illustration of different classes of $G$. boninense internal symptoms (bulb infection) on oil palm seedlings

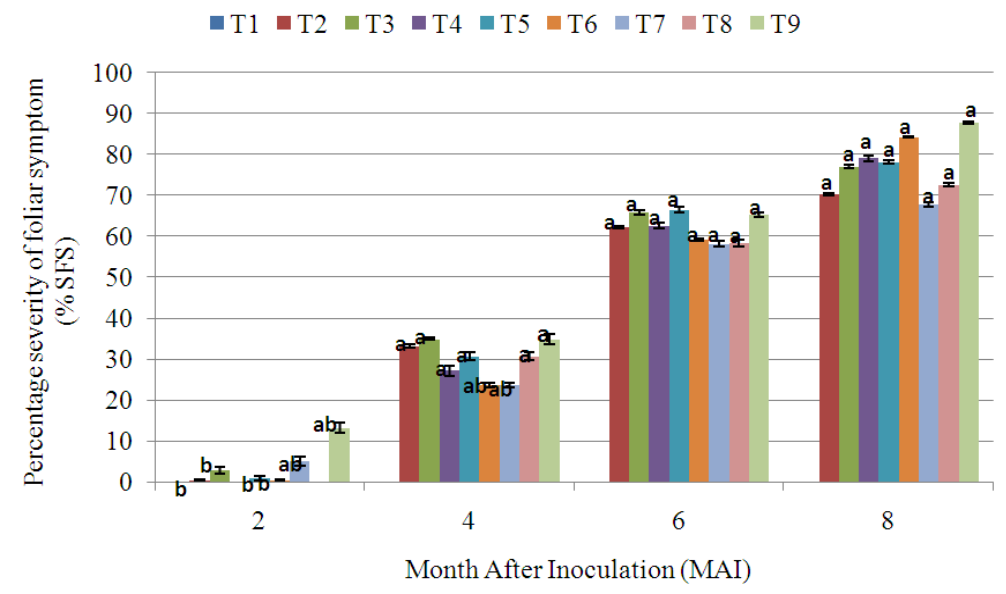

Fig. 6. Percentage severity of foliar symptoms of $G$. boninense on oil palm seedlings supplied with different micronutrientsupplemented fertilizers; Note: Means with the same letter at a given time period are not significantly different according to Duncan's Multiple Range Test (DMRT) at $\alpha=0.05$; values are the means of four replicates. Bars represent standard errors. $\mathrm{T} 1($ Absolute control $)=\mathrm{BF}$ without Ganoderma; $\mathrm{T} 2($ Inoculated control $)=\mathrm{BF}+$ Ganoderma $; \mathrm{T} 3=\mathrm{BF}+\mathrm{B}+$ Ganoderma; $\mathrm{T} 4=\mathrm{BF}+\mathrm{Cu}+$ Ganoderma $; \mathrm{T} 5=\mathrm{BF}+\mathrm{Mn}+$ Ganoderma $; \mathrm{T} 6=\mathrm{BF}+\mathrm{B}+\mathrm{Cu}+$ Ganoderma $; \mathrm{T} 7=\mathrm{BF}+\mathrm{B}+\mathrm{Mn}+$ Ganoderma $; \mathrm{T} 8=\mathrm{BF}+\mathrm{Cu}+\mathrm{Mn}+$ Ganoderma $; \mathrm{T} 9=\mathrm{BF}+\mathrm{B}+\mathrm{Cu}+\mathrm{Mn}+$ Ganoderma 


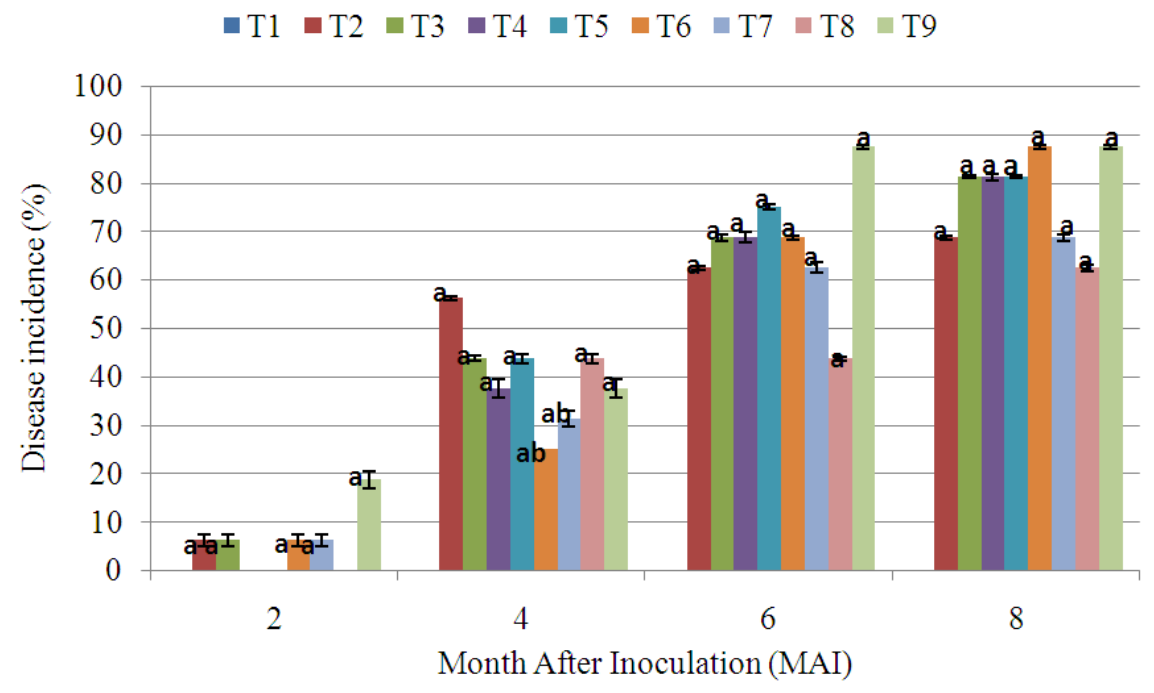

Fig. 7. Ganoderma basal stem rot incidence on oil palm seedlings supplied with different micronutrient-supplemented fertilizers; Note: Means with the same letter at a given time period are not significantly different according to Duncan's Multiple Range Test (DMRT) at $\alpha=0.05$; values are the means of four replicates. Bars represent standard errors. T1 (Absolute control) $=\mathrm{BF}$ without Ganoderma; $\mathrm{T} 2$ (Inoculated control) $=\mathrm{BF}+$ Ganoderma $; \mathrm{T} 3=\mathrm{BF}+\mathrm{B}+$ Ganoderma $; \mathrm{T} 4=\mathrm{BF}+\mathrm{Cu}+$ Ganoderma; $\mathrm{T} 5=\mathrm{BF}+\mathrm{Mn}+$ Ganoderma $; \mathrm{T} 6=\mathrm{BF}+\mathrm{B}+\mathrm{Cu}+$ Ganoderma $; \mathrm{v} \mathrm{T} 7=\mathrm{BF}+\mathrm{B}+\mathrm{Mn}+$ Ganoderma $; \mathrm{T} 8=\mathrm{BF}+\mathrm{Cu}+\mathrm{Mn}+$ Ganoderma $\mathrm{T} 9=\mathrm{BF}+\mathrm{B}+\mathrm{Cu}+\mathrm{Mn}+$ Ganoderma

Table 2. Classification of Ganoderma infection of bulb tissues of oil palm seedlings

\begin{tabular}{ll}
\hline Disease class & Symptom description \\
\hline 0 & Healthy: no rotting of the bulb tissues \\
1 & Rotted area less than 25\% of the bulb area \\
2 & Rotted area between 25 and $50 \%$ of the bulb area \\
3 & Rotted area between 51 and $75 \%$ of the bulb area \\
4 & Rotted area greater than $75 \%$ of the bulb area or total rotting \\
\hline
\end{tabular}

Source: Adapted from Nur Sabrina et al. (2012; Breton et al., 2006)

Table 3. Disease severity index for foliar symptoms of different micronutrient-supplemented fertilizer treatments applied to oil palm seedlings inoculated with $G$. boninense

Disease severity index for foliar symptoms (\%)

\begin{tabular}{lllll} 
Treatment & $2 \mathrm{MAI}$ & $4 \mathrm{MAI}$ & $6 \mathrm{MAI}$ & $8 \mathrm{MAI}$ \\
\hline T1 & $0.00 \pm 0.00^{\mathbf{b}}$ & $0.00 \pm 0.00^{\mathbf{b}}$ & $0.00 \pm 0.0^{\mathbf{b}}$ & $0.00 \pm 0.00^{\mathbf{b}}$ \\
T2 & $1.56 \pm 1.56^{\mathbf{b}}$ & $34.38 \pm 6.50^{\mathbf{a}}$ & $59.38 \pm 5.98^{\mathbf{a}}$ & $65.63 \pm 5.98^{\mathbf{a}}$ \\
T3 & $1.56 \pm 1.56^{\mathbf{b}}$ & $34.38 \pm 4.03^{\mathbf{a}}$ & $62.50 \pm 13.50^{\mathbf{a}}$ & $75.00 \pm 8.84^{\mathbf{a}}$ \\
T4 & $0.00 \pm 0.00^{\mathbf{b}}$ & $25.00 \pm 14.21^{\mathbf{a b}}$ & $60.94 \pm 12.60^{\mathbf{a}}$ & $75.56 \pm 14.06^{\mathbf{a}}$ \\
T5 & $0.00 \pm 0.00^{\mathbf{b}}$ & $31.25 \pm 12.76^{\mathbf{a b}}$ & $68.75 \pm 10.82^{\mathbf{a}}$ & $78.13 \pm 8.27^{\mathbf{a}}$ \\
T6 & $1.56 \pm 1.56^{\mathbf{b}}$ & $18.75 \pm 3.61^{\mathbf{a b}}$ & $60.94 \pm 8.22^{\mathbf{a}}$ & $76.56 \pm 9.67^{\mathbf{a}}$ \\
T7 & $6.25 \pm 6.25^{\mathbf{a b}}$ & $23.44 \pm 8.22^{\mathbf{a b}}$ & $57.81 \pm 12.85^{\mathbf{a}}$ & $60.94 \pm 12.60^{\mathbf{a}}$ \\
T8 & $0.00 \pm 0.00^{\mathbf{b}}$ & $29.69 \pm 11.80^{\mathbf{a b}}$ & $56.25 \pm 11.97^{\mathbf{a}}$ & $67.19 \pm 10.63^{\mathbf{a}}$ \\
T9 & $14.06 \pm 8.22^{\mathbf{a}}$ & $34.38 \pm 13.86^{\mathbf{a}}$ & $73.44 \pm 3.34^{\mathbf{a}}$ & $85.94 \pm 6.44^{\mathbf{a}}$ \\
\hline
\end{tabular}

Note: Means with the same letter at a given time period are not significantly different according to Duncan's Multiple Range Test $(\mathrm{DMRT})$ at $\alpha=0.05$; values are the means of four replicates \pm standard error. $\mathrm{T} 1$ (Absolute control) $=\mathrm{BF}$ without Ganoderma; $\mathrm{T} 2=\mathrm{BF}+$ Ganoderma $; \mathrm{T} 3=\mathrm{BF}+\mathrm{B}+$ Ganoderma $; \mathrm{T} 4=\mathrm{BF}+\mathrm{Cu}+$ Ganoderma $; \mathrm{T} 5=\mathrm{BF}+\mathrm{Mn}+$ Ganoderma; $\mathrm{T} 6=\mathrm{BF}+\mathrm{B}+\mathrm{Cu}+$ Ganoderma $; \mathrm{T} 7=\mathrm{BF}+\mathrm{B}+\mathrm{Mn}+$ Ganoderma $; \mathrm{T} 8=\mathrm{BF}+\mathrm{Cu}+\mathrm{Mn}+$ Ganoderma $; \mathrm{T} 9=\mathrm{BF}+\mathrm{B}+\mathrm{Cu}+$ $\mathrm{Mn}+$ Ganoderma $; \mathrm{MAI}=$ month after inoculation 
Fabien Fonguimgo Tengoua et al. / American Journal of Applied Sciences 11 (10): 1841-1859, 2014

Table 4. Comparative Area under the disease progress curve, disease reduction and epidemic rate of different treatments for the severity of foliar symptoms and disease incidence eight months after inoculation

\begin{tabular}{|c|c|c|c|c|c|c|}
\hline \multirow[b]{2}{*}{ Treatment } & \multicolumn{3}{|c|}{ Severity of foliar symptoms } & \multicolumn{3}{|c|}{ Disease incidence } \\
\hline & AUDPC & DR & ER & AUDPC & DR & ER \\
\hline & Unit $^{2}$ & $\%$ & Unit month $^{-1}$ & Unit $^{2}$ & $\%$ & Unit month $^{-1}$ \\
\hline $\mathrm{T} 2$ & 261.14 & - & 0.21 & 312.5 & - & 0.17 \\
\hline $\mathrm{T} 3$ & 281.18 & -7.67 & 0.25 & 287.5 & 8 & 0.27 \\
\hline $\mathrm{T} 4$ & 258.38 & 1.06 & 0.27 & 293.75 & 6 & 0.28 \\
\hline T5 & 273.11 & -4.58 & 0.26 & 318.75 & -2 & 0.29 \\
\hline T6 & 250.27 & 4.16 & 0.31 & 281.25 & 10 & 0.34 \\
\hline $\mathrm{T} 7$ & 236 & 9.63 & 0.19 & 262.45 & 16.02 & 0.19 \\
\hline $\mathrm{T} 8$ & 250.64 & 4.02 & 0.22 & 237.5 & 24 & 0.15 \\
\hline T9 & 300.7 & -15.15 & 0.32 & 356.25 & -14 & 0.36 \\
\hline
\end{tabular}

Note: $\mathrm{AUDPC}=$ Area under the disease progress curve; $\mathrm{DR}=$ Disease reduction; $\mathrm{ER}=$ Epidemic rate; $\mathrm{T} 2$ (Inoculated control) $=\mathrm{BF}$ + Ganoderma; $\mathrm{T} 3=\mathrm{BF}+\mathrm{B}+$ Ganoderma; $\mathrm{T} 4=\mathrm{BF}+\mathrm{Cu}+$ Ganoderma $; \mathrm{T} 5=\mathrm{BF}+\mathrm{Mn}+$ Ganoderma $; \mathrm{T} 6=\mathrm{BF}+\mathrm{B}+\mathrm{Cu}+$ Ganoderma $; \mathrm{T} 7=\mathrm{BF}+\mathrm{B}+\mathrm{Mn}+$ Ganoderma $\mathrm{T} 8=\mathrm{BF}+\mathrm{Cu}+\mathrm{Mn}+$ Ganoderma $; \mathrm{T} 9=\mathrm{BF}+\mathrm{B}+\mathrm{Cu}+\mathrm{Mn}+$ Ganoderma

Table 5. Percentage of dead oil palm seedlings recorded in different treatments

\begin{tabular}{|c|c|c|c|c|}
\hline \multirow[b]{2}{*}{ Treatment } & \multicolumn{4}{|c|}{ Dead seedlings (\%) } \\
\hline & $2 \mathrm{MAI}$ & $4 \mathrm{MAI}$ & $6 \mathrm{MAI}$ & $8 \mathrm{MAI}$ \\
\hline $\mathrm{T} 1$ & $0.00 \pm 0.00^{\mathbf{b}}$ & $0.00 \pm 0.00^{\mathbf{b}}$ & $0.00 \pm 0.00^{\mathbf{b}}$ & $0.00 \pm 0.00^{\mathbf{b}}$ \\
\hline $\mathrm{T} 2$ & $0.00 \pm 0.00^{\mathbf{b}}$ & $18.75 \pm 6.25^{\mathrm{ab}}$ & $56.25 \pm 6.25^{\mathrm{a}}$ & $62.50 \pm 7.22^{\mathrm{a}}$ \\
\hline $\mathrm{T} 3$ & $0.00 \pm 0.00^{\mathbf{b}}$ & $25.00 \pm 0.00^{\mathbf{a b}}$ & $56.25 \pm 15.73^{\mathrm{a}}$ & $68.75 \pm 11.97^{\mathrm{a}}$ \\
\hline $\mathrm{T} 4$ & $0.00 \pm 0.00^{\mathbf{b}}$ & $12.50 \pm 7.22^{\mathrm{ab}}$ & $50.00 \pm 10.21^{\mathrm{a}}$ & $75.00 \pm 10.21^{\mathrm{a}}$ \\
\hline $\mathrm{T} 5$ & $0.00 \pm 0.00^{\mathbf{b}}$ & $18.75 \pm 11.97^{\mathbf{a b}}$ & $62.50 \pm 12.50^{\mathrm{a}}$ & $68.75 \pm 11.97^{\mathrm{a}}$ \\
\hline T6 & $0.00 \pm 0.00^{\mathbf{b}}$ & $12.50 \pm 7.22^{\mathrm{ab}}$ & $43.75 \pm 11.97^{\mathrm{a}}$ & $75.00 \pm 0.00^{\mathrm{a}}$ \\
\hline $\mathrm{T} 7$ & $6.25 \pm 6.25^{\mathrm{a}}$ & $12.50 \pm 7.22^{\mathrm{ab}}$ & $50.00 \pm 10.21^{\mathrm{a}}$ & $56.25 \pm 11.91^{\mathrm{a}}$ \\
\hline $\mathrm{T} 8$ & $0.00 \pm 0.00^{\mathbf{b}}$ & $18.75 \pm 11.97^{\mathbf{a b}}$ & $50.00 \pm 17.68^{\mathrm{a}}$ & $62.50 \pm 7.22^{\mathrm{a}}$ \\
\hline T9 & $12.50 \pm 7.22^{\mathrm{ab}}$ & $31.25 \pm 11.97^{\mathrm{a}}$ & $56.25 \pm 11.97^{\mathrm{a}}$ & $81.25 \pm 6.25^{\mathrm{a}}$ \\
\hline
\end{tabular}

Note: Means with the same letter at a given time period are not significantly different according to Duncan's Multiple Range Test $(\mathrm{DMRT})$ at $\alpha=0.05$; values are the means of four replicates \pm standard error. T1 (Absolute control) ) $=\mathrm{BF}$ without Ganoderma; $\mathrm{T} 2$ (Inoculated control $)=\mathrm{BF}+$ Ganoderma $; \mathrm{T} 3=\mathrm{BF}+\mathrm{B}+$ Ganoderma $; \mathrm{T} 4=\mathrm{BF}+\mathrm{Cu}+$ Ganoderma $; \mathrm{T} 5=\mathrm{BF}+\mathrm{Mn}+$ Ganoderma $; \mathrm{T} 6$ $=\mathrm{BF}+\mathrm{B}+\mathrm{Cu}+$ Ganoderma $; \mathrm{T} 7=\mathrm{BF}+\mathrm{B}+\mathrm{Mn}+$ Ganoderma $; \mathrm{T} 8=\mathrm{BF}+\mathrm{Cu}+\mathrm{Mn}+$ Ganoderma $; \mathrm{T} 9=\mathrm{BF}+\mathrm{B}+\mathrm{Cu}+\mathrm{Mn}+$ Ganoderma; MAI = Month After Inoculation

Table 6. Percentage of infected roots and disease severity index for root symptoms of different treatments eight months after inoculation

\begin{tabular}{lll}
\hline Treatment & Percentage of infected roots & Disease severity index for root symptoms \\
\hline T1 & $0.00 \pm 0.00^{\mathbf{b}}$ & $0.00 \pm 0.00^{\mathbf{b}}$ \\
T2 & $60.92 \pm 8.77^{\mathbf{a}}$ & $62.50 \pm 9.20^{\mathbf{a}}$ \\
T3 & $66.95 \pm 11.05^{\mathbf{a}}$ & $68.75 \pm 10.52^{\mathbf{a}}$ \\
T4 & $75.31 \pm 15.23^{\mathbf{a}}$ & $76.56 \pm 14.06^{\mathbf{a}}$ \\
T5 & $80.16 \pm 7.32^{\mathbf{a}}$ & $81.25 \pm 6.75^{\mathbf{a}}$ \\
T6 & $84.26 \pm 5.96^{\mathbf{a}}$ & $84.38 \pm 5.98^{\mathbf{a}}$ \\
T7 & $67.54 \pm 10.25^{\mathbf{a}}$ & $70.31 \pm 8.97^{\mathbf{a}}$ \\
T8 & $69.47 \pm 10.79^{\mathrm{a}}$ & $73.44 \pm 9.67^{\mathbf{a}}$ \\
T9 & $87.50 \pm 7.22^{\mathbf{a}}$ & $87.50 \pm 7.22^{\mathrm{a}}$ \\
\hline
\end{tabular}

Note: Means with the same letter for a given parameter are not significantly different according to Duncan's Multiple Range Test (DMRT) at $\alpha=0.05$; values are the means of four replicates \pm standard error. T1 (Absolute control) $=\mathrm{BF}$ without Ganoderma; $\mathrm{T} 2$ (Inoculated control) $=\mathrm{BF}+$ Ganoderma $; \mathrm{T} 3=\mathrm{BF}+\mathrm{B}+$ Ganoderma $; \mathrm{T} 4=\mathrm{BF}+\mathrm{Cu}+$ Ganoderma $; \mathrm{T} 5=\mathrm{BF}+$ $\mathrm{Mn}+$ Ganoderma $\mathrm{T} 6=\mathrm{BF}+\mathrm{B}+\mathrm{Cu}+$ Ganoderma $; \mathrm{T} 7=\mathrm{BF}+\mathrm{B}+\mathrm{Mn}+$ Ganoderma $; \mathrm{T} 8=\mathrm{BF}+\mathrm{Cu}+\mathrm{Mn}+$ Ganoderma $; \mathrm{T} 9$ $=\mathrm{BF}+\mathrm{B}+\mathrm{Cu}+\mathrm{Mn}+$ Ganoderma 
Up to five months after inoculation, differences among treatments in DSIF and the percentage of dead seedlings were significant. Treatment T6 $(\mathrm{B}+\mathrm{Cu})$ had the lowest DSIF and the lowest percentage of dead plants and the inoculated control T2 the highest; however, from the seventh month on, there were fewer or no differences observed among treatments for almost all of the parameters evaluated. This could indicate that the micronutrients under study might have some positive effects in reducing Ganoderma infection; but that seedlings might have been too young (four-month-old) to withstand high inoculum pressure to suggest that, as mentioned earlier, three months pre-treatment might have not been enough time to allow the development of a strong defence system before inoculation.

\subsection{Percentage of Infected Roots and Disease Severity Index for Root Symptoms}

Variations in the percentage of infected roots were observed among different treatments (Table 6); however, there were no significant differences among the inoculated treatments. It is worth mentioning that the highest percentage of root infection (87.50\%) was recorded in $\mathrm{T} 9$ and the lowest with $\mathrm{T} 2(60.90 \%)$. This indicates that the addition of $\mathrm{B}+\mathrm{Cu}+\mathrm{Mn}$ to the basic NPK fertilizer predisposed oil palm seedlings to Ganoderma infection to thereby cancel any beneficial effect of the individual micronutrient-supplemented fertilizers in mitigating BSR infection. Among the other micronutrient-supplemented treatments, T3 and T7 also resulted in a low percentage of root infection, close to $\mathrm{T} 2$, at 66.95 and $67.54 \%$, respectively, suggesting less predisposition with $\mathrm{B}$ alone and $\mathrm{B}+\mathrm{Mn}$ on root infection by $G$. boninense.

The $\mathrm{B}+\mathrm{Cu}$ treatment (T6) had the highest percentage of bulb tissue decayed, followed by $\mathrm{T} 9$, with respectively, 75.83 and $74.92 \%$ of the bulb tissues infected. The lowest bulb infection was with $\mathrm{B}+\mathrm{Mn}$ (T7) at $57.67 \%$. This indicates that the combined B + Mn may predispose less to (or delay) the expansion of Ganoderma infection in the bulb while $\mathrm{B}+\mathrm{Cu}$, as well as $\mathrm{B}+\mathrm{Cu}+\mathrm{Mn}$ might predispose bulb tissues to easy maceration by this pathogen although none of the treatments were significantly different.

\subsection{Bulb Area}

The estimation of bulb area (Table 7) at the end of the experiment showed that Ganoderma infection drastically and significantly $(\mathrm{p} \leq 0.05)$ reduced the total bulb area compared to the non-inoculated control. The reduction rate was $66.38 \%$ between the most infected treatment T9 $\left(6.34 \mathrm{~cm}^{2}\right)$ and the absolute control T1 $\left(18.86 \mathrm{~cm}^{2}\right)$. Although the differences observed among inoculated treatments were not significant, treatments T8, T7 and T3 had higher values for total bulb area (8.90, 8.30 and $8.22 \mathrm{~cm}^{2}$, respectively), stressing once more the positive contribution of combined $\mathrm{Cu}$ and $\mathrm{Mn}$, combined B and $\mathrm{Mn}$ and $\mathrm{B}$ alone relative to BSR on oil palm seedlings. Treatment T9 again exhibited the worst performance $\left(6.34 \mathrm{~cm}^{2}\right)$, close to that of $\mathrm{T} 4\left(6.37 \mathrm{~cm}^{2}\right)$.

\subsection{Percentage of Infected Bulb Tissues and Disease Severity Index for Bulb Symptoms}

There was no significant difference observed among inoculated treatments for the percentage of bulb tissues decayed (Table 8) but the $\mathrm{B}+\mathrm{Cu}$ Treatment (T6) had the highest percentage of infected bulb tissues $(75.83 \%)$, followed by $\mathrm{B}+\mathrm{Cu}+\mathrm{Mn}$ (T9) $(74.92 \%)$. The treatment $\mathrm{B}+\mathrm{Mn}$ (T7) had the lowest percentage of bulb tissues infected by $G$. boninense to suggest a delay in disease progress by $\mathrm{B}+\mathrm{Mn}$ added to the basic fertilizer.

Differences in the Disease Severity Index for Bulb symptoms (DSIB) were not significant, but followed the same trend observed for the percentage of infected bulb tissues whereby the $\mathrm{B}+\mathrm{Cu}$ treatment (T6) had the highest DSIB $(82.81 \%)$ followed by T9 $(79.69 \%)$, while T7 gave the lowest index $(62.50 \%)$. The same indication of some potential of combined $\mathrm{B}+\mathrm{Mn}$ to impair Ganoderma progress compared to combined $\mathrm{B}+\mathrm{Cu}$ and $\mathrm{B}+\mathrm{Cu}+\mathrm{Mn}$ can be stated; however, this effect also may be from the $\mathrm{B}$ treatment alone. It could also be stated that $\mathrm{Cu}$ or $\mathrm{Mn}$ tended to increase disease severity.

A positive RWB can reflect the degree of inoculum pressure on oil palm seedlings. Thus, in spite of the high inoculum pressure exerted by $G$. boninense as indicated by almost $100 \%$ positive RWB, the $\mathrm{B}+\mathrm{Mn}$ (T7), $\mathrm{Cu}+$ Mn (T8) and, to a slight extent, B + Cu (T6) had less mycelium and fruiting body development compared to the other treatments considered under lower pressure (Table 9). This could suggest that $\mathrm{T} 7(\mathrm{~B}+\mathrm{Mn})$ and $\mathrm{T} 8$ $(\mathrm{Cu}+\mathrm{Mn})$ suppress $G$. boninense better than all the other treatments; however, this was not reflected in significantly reduced disease severity (Table 8).

Overall, B, $\mathrm{Cu}$ and $\mathrm{Mn}$ were shown to influence Ganoderma BSR on oil palm seedlings. The effects observed are either synergistic when these elements are applied in double combinations, or antagonistic when they are supplied in triple combination. Taken individually, their effects are not as positive as their combinations. 
Table 7. Effects of $\mathrm{B}, \mathrm{Cu}$ and $\mathrm{Mn}$-supplemented fertilizers on the bulb area of oil palm seedlings eight months after inoculation with $G$. boninense

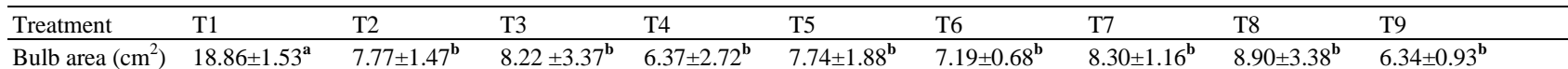

Note: Means with the same letter are not significantly different according to Duncan's Multiple Range Test (DMRT) at $\alpha=0.05$; values are the means of four replicates \pm standard error. $\mathrm{T} 1($ Absolute control $)=\mathrm{BF}$ without Ganoderma; $\mathrm{T} 2($ Inoculated control $)=$ $\mathrm{BF}+$ Ganoderma $; \mathrm{T} 3=\mathrm{BF}+\mathrm{B}+$ Ganoderma $\mathrm{T} 4=\mathrm{BF}+\mathrm{Cu}+$ Ganoderma $; \mathrm{T} 5=\mathrm{BF}+\mathrm{Mn}+$ Ganoderma $; \mathrm{T} 6=\mathrm{BF}+\mathrm{B}+\mathrm{Cu}+$ Ganoderma $\mathrm{T} 7=\mathrm{BF}+\mathrm{B}+\mathrm{Mn}+$ Ganoderma $; \mathrm{T} 8=\mathrm{BF}+\mathrm{Cu}+\mathrm{Mn}+$ Ganoderma $; \mathrm{T} 9=\mathrm{BF}+\mathrm{B}+\mathrm{Cu}+\mathrm{Mn}+$ Ganoderma $; \mathrm{T} 9=\mathrm{BF}$ $+\mathrm{B}+\mathrm{Cu}+\mathrm{Mn}+$ Ganoderma

Table 8. Percentage of infected bulb tissues and disease severity index for bulb symptoms eight months after inoculation

\begin{tabular}{lll}
\hline Treatment & Percentage infected bulb tissue & Disease severity index for bulb symptoms \\
\hline T1 & $0.00 \pm 0.00^{\mathbf{b}}$ & $0.00 \pm 0.00^{\mathbf{b}}$ \\
T2 & $64.61 \pm 6.24^{\mathrm{a}}$ & $65.63 \pm 5.98^{\mathrm{a}}$ \\
T3 & $60.70 \pm 13.39^{\mathrm{a}}$ & $62.50 \pm 12.76^{\mathrm{a}}$ \\
T4 & $70.70 \pm 15.07^{\mathrm{a}}$ & $73.44 \pm 14.96^{\mathrm{a}}$ \\
T5 & $69.49 \pm 8.51^{\mathrm{a}}$ & $71.88 \pm 8.27^{\mathbf{a}}$ \\
T6 & $75.83 \pm 5.10^{\mathrm{a}}$ & $82.81 \pm 5.34^{\mathrm{a}}$ \\
T7 & $57.69 \pm 12.17^{\mathrm{a}}$ & $62.50 \pm 12.24^{\mathrm{a}}$ \\
T8 & $63.26 \pm 11.69^{\mathrm{a}}$ & $65.63 \pm 11.55^{\mathrm{a}}$ \\
T9 & $74.92 \pm 4.05^{\mathrm{a}}$ & $79.69 \pm 5.34^{\mathrm{a}}$ \\
\hline
\end{tabular}

Note: means with the same letter for a given parameter are not significantly different according to Duncan's Multiple Range Test (DMRT) at $\alpha=0.05$; values are the means of four replicates \pm standard error. T1 (Absolute control) $=\mathrm{BF}$ without Ganoderma; $\mathrm{T} 2$ (Inoculated control) $=\mathrm{BF}+$ Ganoderma $; \mathrm{T} 3=\mathrm{BF}+\mathrm{B}+$ Ganoderma $; \mathrm{T} 4=\mathrm{BF}+\mathrm{Cu}+$ Ganoderma $; \mathrm{T} 5=\mathrm{BF}+$ $\mathrm{Mn}+$ Ganoderma $; \mathrm{T} 6=\mathrm{BF}+\mathrm{B}+\mathrm{Cu}+$ Ganoderma $; \mathrm{T} 7=\mathrm{BF}+\mathrm{B}+\mathrm{Mn}+$ Ganoderma $; \mathrm{T} 8=\mathrm{BF}+\mathrm{Cu}+\mathrm{Mn}+$ Ganoderma $; \mathrm{T} 9$ $=\mathrm{BF}+\mathrm{B}+\mathrm{Cu}+\mathrm{Mn}+$ Ganoderma

Table 9. Summary of fungal structures observed on inoculated seedlings in different treatments and number of positive rubber wood blocks

\begin{tabular}{|c|c|c|c|c|c|c|c|c|c|}
\hline \multirow[b]{2}{*}{ Fungal structure } & \multicolumn{8}{|c|}{ Treatment } & \multirow[b]{2}{*}{ Total } \\
\hline & $\mathrm{T} 2$ & $\mathrm{~T} 3$ & $\mathrm{~T} 4$ & T5 & T6 & $\mathrm{T} 7$ & $\mathrm{~T} 8$ & T9 & \\
\hline Mycelium & 11 & 13 & 13 & 13 & 14 & 11 & 11 & 14 & $100(78.12 \%)$ \\
\hline White button/Basidiomata & 6 & 7 & 5 & 7 & 4 & 4 & 5 & 6 & $44(34.37 \%)$ \\
\hline Positive RWB & 14 & 12 & 14 & 15 & 16 & 15 & 15 & 15 & $116(90.62 \%)$ \\
\hline
\end{tabular}

Note: Average of 16 oil palm seedlings for each treatment; $\mathrm{T} 2$ (Inoculated control) $=\mathrm{BF}+$ Ganoderma; $\mathrm{T} 3=\mathrm{BF}+\mathrm{B}+$ Ganoderma; $\mathrm{T} 4=\mathrm{BF}+\mathrm{Cu}+$ Ganoderma $\mathrm{T} 5=\mathrm{BF}+\mathrm{Mn}+$ Ganoderma $; \mathrm{T} 6=\mathrm{BF}+\mathrm{B}+\mathrm{Cu}+$ Ganoderma $; \mathrm{T} 7=\mathrm{BF}+\mathrm{B}+\mathrm{Mn}+$ Ganoderma $; \mathrm{T} 8$ $=\mathrm{BF}+\mathrm{Cu}+\mathrm{Mn}+$ Ganoderma $; \mathrm{T} 9=\mathrm{BF}+\mathrm{B}+\mathrm{Cu}+\mathrm{Mn}+$ Ganoderma

These variations reflect the inconsistency of the effects of micronutrients on disease pointed out by Marschner (2012). The antagonism of the triple combination is quite difficult to explain and shows how complicated and interdependent the interrelationships are between nutrients in the plant system (Ranade-Malvi, 2011). This negative effect of $\mathrm{B}+\mathrm{Cu}+\mathrm{Mn}$ is somewhat similar to the results of Jones and Woltz (1970) who found that Fe $+\mathrm{Mn}+\mathrm{Zn}$ or $\mathrm{Fe}+\mathrm{Mn}$ did not nullify the positive effect of liming in reducing Fusarium wilt of tomato incited by Fusarium oxysporum f. sp. lycopersici, while $\mathrm{Fe}+\mathrm{Zn}$ and $\mathrm{Mn}+\mathrm{Zn}$ reversed it. They stated that why certain combinations of micronutrients encouraged wilt development whereas others did not is not known.
Boron, $\mathrm{Cu}$ and $\mathrm{Mn}$ use various mechanisms to control plant diseases. As pointed out by (Graham and Webb, 1991), there is no conclusive evidence which explains how B decreases diseases caused by vascular or soilborne pathogens. That is, it is difficult to determine at which point in pathogenesis B has an effect. Lignified tissues constitute a physical barrier suggested as a mechanism used by $\mathrm{B}$ to inhibit invasion of xylem by pathogen (Lewis, 1980). Other mechanisms include retardation in the movement of fungal hyphae through the cortex (Graham and Webb, 1991), improvement of pectin synthesis or stabilization to strengthen middle lamella and make them suppressive or less conducive to hyphae penetration since many root-infecting pathogens synthesize pectinases (Marschner, 2012). Boron also 
reduces some plant diseases thanks to its role in the production of antifungal phenolic/lignin metabolism (Graham and Webb, 1991). Another defence mechanism of $\mathrm{B}$ is the formation of papillae to block pathogen penetration. The papillae are said to contain both lignin and callose whose synthesis is influenced by B (Lewis, 1980; Shimomura, 1982; Marschner, 1986; Cadena-Gomez and Nicholson, 1987). In the present study, $\mathrm{B}$ in synergy with $\mathrm{Mn}$ or $\mathrm{Cu}$ may have reduced BSR most probably by retarding $G$. boninense hyphae progression in root cortex and bulb tissues rather than by lignin synthesis (Lewis, 1980) because $G$. boninense is an efficient lignin-degrader. Moreover, from the early results of this study, it appeared that lignin could not be a good criterion to differentiate susceptible and tolerant oil palm progenies.

Copper participates with $\mathrm{B}$ in lignification as a plant defence strategy against plant pathogens. Specific mechanisms employed by $\mathrm{Cu}$ to reduce plant diseases include direct toxicity to pathogens (Huber, 1989; Evans et al., 2007) and enhancement of plant resistance to disease as a regulator or a cofactor of many enzymes involved in plant defence (Graham, 1983; Graham and Webb, 1991). The effect of $\mathrm{Cu}$ on pathogen virulence might be the most important mechanism to scrutinise in the present study. Copper is an essential micronutrient for pathogens, plants and animals (Evans et al., 2007). White-rotting fungi such as $G$. boninense have $\mathrm{Cu}$-containing enzymes, laccases, among their complex enzymatic system to degrade the wood. Laccases constitute an important virulence factor for many plant-pathogenic fungi which enables them to degrade physical barriers, such as lignin and detoxify phytoalexins and tannins in the infection site (Mayer and Staples, 2002). The detoxification of tannic acid in Ganoderma Selective Medium (GSM) is revealed by the brown coloration exploited to confirm the internal colonization of RWB by $G$. boninense. It is also conceivable that in the absence of $\mathrm{B}$ and $\mathrm{Mn}, \mathrm{Cu}$ alone supplied to the soil for plant use was mostly diverted to meet $G$. boninense needs which may explain the poorer performance of treatment $\mathrm{T} 4(\mathrm{Cu})$ in this study. On the other hand, in the presence of $\mathrm{B}$ or $\mathrm{Mn}, \mathrm{Cu}$ may have been able to express its defence potentials against $G$. boninense. For the reason mentioned earlier, lignin or lignification is less likely to be efficient to counteract $G$. boninense. In synergy with $\mathrm{B}$ or $\mathrm{Mn}, \mathrm{Cu}$ may have improved the resistance of oil palm seedlings in different ways. The positive effect of $\mathrm{Cu}+\mathrm{Mn}$ could be explained by synergistic action and improvement of $\mathrm{Cu}$ net uptake by
Mn as reported by Fageria (2001). Being a component of polyphenol oxidase (Graham and Webb, 1991), $\mathrm{Cu}$ involvement in the synthesis of soluble phenols and in their oxidation to toxic quinones such as caffeic quinones to kill $G$. boninense is conceivable, but was not manifest in the RWB. Copper deficiency has a primary effect on the content of phenolic constituents of the cell walls (Robson et al., 1981). Phenolic compounds are known to be implicated especially in the resistance of plants to diseases of fungal origin (Graham, 1980). Terpenoids, such as sesquiterpenoids, are another group of secondary metabolites which accumulate in plants in response to $\mathrm{Cu}$ treatment (Chmielowska et al., 2010). This antimicrobial compound, together with soluble phenolics, should have contributed to reduced $G$. boninense effects on oil palm seedlings, but most parameters for disease were increased by $\mathrm{Cu}$.

Besides its involvement, like $\mathrm{B}$ and $\mathrm{Cu}$, in lignin biosynthesis as a defence mechanism, Mn can indirectly act on the pathogen by improving the production of toxic compounds (phenolics, phytoalexins), which inhibit pathogen growth, enzyme production, replication and sporulation (Huber and Wilhelm, 1988; Thompson and Huber, 2007). The oxidation of soluble phenols into oxidized forms toxic to fungi and involved in plant defence is under the control of Mn-containing enzymes (Graham, 1983). The enhancement of plant resistance indirectly through root exudates to modify the root environment, or the modification of important metabolic constituents required for pathogenic activity is also reported (Thompson and Huber, 2007). By activating important biochemical reactions in plant defence, such as the production of phenylalanine ammonia lyase, the first enzyme committed in the phenylpropanoid pathway, Mn increases the deposition of recalcitrant lignin to slow down fungal invasion (Burnell, 1988). The formation of lignitubers was found to halt the development of take-all of wheat caused by Gaeumannomyces graminis var. tritici (Huber and Wilhelm, 1988). The efficiency of lignin or lignitubers in halting fungal invasion could be explained by the incapacity of the pathogen to decompose the lignin component of the barrier. In the present research, this mechanism is less important. Manganese-peroxidase is part of the enzymatic system used by white rot fungi in their wood decaying activity. It is possible that individual Mn added to NPK fertilizer in its reduced form (Mn (II)) was oxidized by Ganoderma Mnoxidizing enzymes, namely Mn-peroxidase, to Mn (IV), 
to nullify or reduce its beneficial effect in reducing BSR on oil palm seedlings. The function of $\mathrm{Mn}$ oxidation in fungi is believed to primarily involve the depolymerisation of lignin, using Mn (III) as the final redox mediator in the breakup of randomly assembled, enzyme-resistant polyphenolic structures (Thompson and Huber, 2007). The oxidation of Mn is said to be the sole reaction performed by Mn-peroxidase (Thompson and Huber, 2007) and requires reduced $\mathrm{Mn}$ as a cofactor (Glenn et al., 1986). When Mn-peroxidase oxidizes Mn (II) to Mn (III), the Mn (III) complexed to lactate or other alpha-hydroxy acids is able to oxidize all of the compounds which are oxidized by the enzymatic system (Glenn et al., 1986). In this study, $\mathrm{Mn}$ in synergy with $\mathrm{B}$ or $\mathrm{Cu}$ may have been available for oxidation by Ganoderma Mn-oxidizing enzymes. From the lower Epidemic Rate (ER) indicative of slower disease development and lower percentage of infected bulb area, among other good performances, observed with $\mathrm{B}+\mathrm{Mn}(\mathrm{T} 7)$ and $\mathrm{Cu}+\mathrm{Mn}(\mathrm{T} 8)$, it can be postulated that in association with either $\mathrm{B}$ or $\mathrm{Cu}$, Mn exerted its influence on host resistance to $G$. boninense by improving the defence system of oil palm seedlings. The direct effect of $\mathrm{Mn}$ on $G$. boninense is also possible as observed by (Mortvedt et al., 1961; 1963) who found that the amount of Mn absorbed by potato was not the control factor for scab caused by Streptomyces scabies, but the direct effect of water soluble soil Mn on the pathogen itself. Furthermore, Mortvedt et al. (1961) observed that adding from 2 to $20 \mathrm{mg} \mathrm{Mn} / \mathrm{kg}$ to the soil surrounding potato tubers reduced scab; however, as shown for most of the treatments and parameters in the present study, they found that the difference required for significance was high but that there was a constant decrease in scab incidence as Mn levels were increased, with $20 \mathrm{mg} \mathrm{kg}^{-1}$ giving a scab incidence of zero.

In the previous experiments, $\mathrm{Mn}$ appeared to be toxic to oil palm seedlings at $5 \mathrm{mg} \mathrm{L}^{-1}$ in solution culture and negatively affected the growth of oil palm seedlings singly or in combination with $\mathrm{B}$ and $\mathrm{Cu}$ in solution culture at $2 \mathrm{mg} \mathrm{L}^{-1}$. However, in soil, the 2 $\mathrm{mg} / \mathrm{kg}$ in combination with $\mathrm{B}$ or $\mathrm{Cu}$ reduced Ganoderma infection better than the single micronutrients or their triple combination. Hence, it is believed that additional Mn might not be needed for oil palm with regard to the initial results and other reports (Corley and Tinker, 2003; Goh and Härdter, 2003). The present results showed that the addition of $\mathrm{Mn}+\mathrm{B}$ or $\mathrm{Mn}+\mathrm{Cu}$ to fertilizer applied to inoculated- oil palm seedlings may reduce Ganoderma incidence and severity slightly. The additional amount of $\mathrm{Mn}$ seldom leads to phytotoxicity since it is well known that under acidic and poor drainage conditions, oil palm is able to accumulate up to $800-1000 \mathrm{mg} \mathrm{Mn} / \mathrm{kg}$ without visible signs of toxicity (Munevar, 2001).

\section{CONCLUSION}

The results of this study indicate that the double combinations of the selected micronutrients could perform better than the individual nutrients and their triple combination on pathological parameters although none were generally significantly different from the control. Among the double combinations, B + Mn (T7) and $\mathrm{Cu}+\mathrm{Mn}$ (T8) generally gave better results than $\mathrm{B}$ $+\mathrm{Cu}$ (T6) for nearly all the parameters investigated. The only individual nutrient which performed well was $B$ with a lower epidemic rate for the percentage or severity of foliar symptoms, lower percentage of infected roots and lower disease severity index for root symptoms, lower disease severity index for infected bulb tissues and higher total bulb area. Subject to confirmative field tests, $\mathrm{B}+\mathrm{Mn}$ and $\mathrm{Cu}+\mathrm{Mn}$, should be considered as combinations to integrate into the oil palm fertilization programme to reduce Ganoderma BSR incidence and severity.

\section{ACKNOWLEDGEMENT}

The researchers would like to thank Emeritus Professor Dr. Don M. Huber from Purdue University, USA, for reading the manuscript and suggesting changes to improve its quality. The staffs of Ganoderma and Disease Research of Oil Palm (GanoDROP) Unit, Malaysian Palm Oil Board (MPOB) are highly appreciated for their assistance in destructive sampling. This study was supported by Universiti Putra Malaysia and DIVERSATECH (M) SDN. BHD.

\section{REFERENCES}

Ariffin, D. and A.S. Idris, 1992. The GanodermaSelective Medium (GSM). Palm Oil Research Institute of Malaysia (PORIM) Information Series.

Ariffin, D., A.S. Idris and G. Singh, 2000. Status of Ganoderma in Oil Palm. In: Ganoderma Disease of Perennial Crops, Flood, J., P.D. Bridge and M. Holderness (Eds.)., CABI Publishing, UK, ISBN-10: 9780851993881, pp: 49-68. 
Abdullah, M., M. Al-Hazmi, E.A. Ayoola, M. Abdurahman and S. Banzal et al., 2003. Epidemic rift valley fever in Saudi Arabia: A clinical study of severe illness in humans. Clin. Infect. Dis., 36: 245252. DOI: $10.1086 / 345671$

Breton, F., Y. Hasan, Hariadi, Z. Lubis and H. De Franqueville, 2006. Characterization of parameters for the development of an early screening test for basal stem rot tolerance in oil palm progenies. J. Oil Palm Res., 2006: 24-36.

Burnell, J.N., 1988. The Biochemistry of Manganese in Plants. In: Manganese in Soils and Plants, Graham, R.D., R.J. Hannam and N.C. Uren (Eds.)., Kluwer Academic Publishers, Dordrecht, Netherlands, ISBN-10: 978-94-009-2817-6, pp: 125-137.

Cadena-Gomez, G. and R.L. Nicholson, 1987. Papilla formation and associated peroxidase activity: A non-specific response to attempted fungal penetration of maize. Physiol. Molecular Plant Pathol., 31: 51-67. DOI: 10.1016/08855765(87)90006-3

Campbell, C.L. and L.V. Madden, 1990. Introduction to Plant Disease Epidemiology. 1st Edn., John Wiley and Sons, Inc. USA, ISBN-13: 9780471832362, pp: 532.

Chmielowska, J., J. Veloso, J. Gutiérrez, C. Silvar and J. Díaz, 2010. Cross-protection of pepper plants stressed by copper against a vascular pathogen is accompanied by the induction of a defence response. Plant Sci., 178: 176-182. DOI: 10.1016/j.plantsci.2009.11.007

Corley, R.H.V. and P.B. Tinker, 2003. The Oil Palm. 4th Edn,. Blackwell Science Ltd, Oxford, ISBN-10: 978-0-632-05212-7, pp: 562.

Evans, I., E. Solberg and D.M. Huber, 2007. Copper and Plant Disease. In: Mineral Nutrition and Plant Disease, Datnoff, L.E., W.H. Elmer and D.M. Huber (Eds.)., APS Press St. Paul, Minnesota, USA, ISBN10: 978-0-89054-346-7, pp: 177-188.

Fageria, V.D., 2001. Nutrient interactions in crop plants. J. Plant Nutrit., 24: 1269-1290. DOI: 10.1081/PLN100106981

Flood, J. and Y. Hasan, 2004. Basal stem rot-taxonomy, biology, epidemiology, economic status and control in South East Asia and Pacific Islands. Proceedings of the International Conference on Pests and Diseases of Importance to the Oil Palm Industry. Fostering Global Cooperation in Instituting Quarantine Shield, May 18-19, Kuala Lumpur, Malaysia, pp: 18-18.
Glenn, J.K., L. Akileswaran and M.H. Gold, 1986. Mn (II) oxidation is the principal function of the extracellular Mn-peroxidase from Phanerochaete chrysosporium. Arch. Biochem. Biophys., 251: 688-696. DOI: 10.1016/0003-9861(86)90378-4

Goh, K.J. and R. Härdter, 2003. General Oil Palm Nutrition. In: Oil Palm: Management for Large and Sustainable Yield, Fairhurst, T. and R. Härdter (Eds.)., Potash and Institute (PPI), Potash and Institute of Canada (PPIC) and International Potash institute (IPI), ISBN-10: 981-04-8485-2, pp: 191-228.

Graham, R.D., 1980. Susceptibility to powdery mildew of wheat plants deficient in copper. Plant Soil, 56: 181-185. DOI: 10.1007/BF02197968

Graham, R.D., 1983. Effects of nutrient stress on susceptibility of plants to disease with particular reference to the trace elements. Adv. Botanical Res., 10: 221-276. DOI: 10.1016/S00652296(08)60261-X

Graham, R.D. and M.J. Webb, 1991. Micronutrients and Disease Resistance and Tolerance in Plants. In: Micronutrients in Agriculture, Mortvedt, J.J., F.R. Cox, L.M Shuman and R.M. Welch (Eds.),, Soil Science Society of America, Inc. Madison, Wisconsin, ISBN-10: 0891187979, pp: 329-370.

Huber, D.M. and N.S. Wilhelm, 1988. The Role of Manganese in Resistance to Plant Diseases. In: Manganese in Soils and Plants, Graham, R.D., R.J. Hannam and N.C. Uren (Eds.)., Kluwer Academic Publishers, Dordrecht, Netherlands, ISBN: 978-94-009-2817-6, pp: 155-173.

Huber, D.M., 1989. The Role of Nutrition in the Takeall Disease of Wheat and other Small Grains. In: Soilborne Plant Pathogens: Management of Diseases with Macro-and Microelements, Engelhard, A.W. (Ed.)., APS Press, St Paul, Minnesota, ISBN-10: 0-89054-101-9, pp: 46-74.

Idris, B.A.S., 1999. Basal Stem Rot (BSR) of Oil Palm (Elaeis Guineensis Jacq.) in Malaysia: Factors Associated with Variation in Disease Severity. PhD Theses, Wye College, University of London, UK.

Idris, A.S., 2009. Basal stem rot in Malaysia-biology, economic importance, epidemiology, detection and control. Proceedings of the MPOB-IOPRI International Workshop on Awareness, Detection and Control of Oil Palm Devastating Diseases, (PDD’ 09), Kuala Lumpur Convention Centre, Kuala Lumpur, Malaysia, pp: 48-48. 
Idris, A.S., 2011. Other Devastating Diseases of Oil Palm. In: Further Advances in oil Palm Research, Basri, M.W., Y.M. Choo and K.W. Chan, (Eds.)., Malaysian Palm Oil Board, ISBN-10: 9679611795, pp: 522-542.

Idris, A.S., M.H.A.Z. Mior, S.M. Maizatul and A. Kushairi, 2011. Survey on status of Ganoderma disease of oil palm in Malaysia 2009-2010. Proceedings of the PIPOC 2011 International Palm Oil Conference. "Palm Oil: Fortifying and Energizing the World". Agriculture, Biotechnology and Substainability Conference, Nov. 15-17, Kuala Lumpur Convention Centre, Kuala Lumpur, Malaysia, pp: 235-238.

Ilias, G.N.M., 2000. Trichoderma Pers. Ex Fr. and its Efficacy as a Bio-Control Agent of Basal Stem rot of Oil Palm (Elaeis Guineensis Jacq.). Unpublished Dissertation in Partial Fulfilment of the Requirements for the Degree of Doctor of Philosophy. 1st Edn., Faculty of Science and Environmental Studies, Universiti Putra Malaysia, Selangor, Malaysia, pp: 283.

Izzati, N.A.M.Z. and A. Faridah, 2008. Disease suppression in Ganoderma-infected oil palm seedlings treated with Trichoderma harzianum. Plant Protect. Sci., 44: 101-107.

Jones, J.P. and S.S. Woltz, 1970. Fusarium wilt of tomato: Interaction of soil liming and micronutrient amendment on disease development. Phytopathology, 6: 812-813. DOI: 10.1094/Phyto60-812

Kandan, A., R. Radjacommare, A. Ramanathan, T. Raguchander and R. Samiyappan et al., 2009. Molecular biology of Ganoderma pathogenicity and diagnosis in coconut seedlings. Folia Microbiol., 54: 147-152. DOI: 10.1007/s12223-009-0022-9

Khairudin, H. and C.C. Tey, 2008. An overview of the current status of Ganoderma basal stem rot and its management in a large plantation group in Malaysia. Planter, 84: 469-482.

Lewis, D.H., 1980. Are there inter-relations between the metabolic role of boron, synthesis of phenolic phytoalexins and the germination of pollen. New Phytologist, 84: 261-270. DOI: 10.1111/j.14698137.1980.tb04426.x

Marschner, H., 1986. Mineral Nutrition of Higher Plants. 1st Edn., Academic Press, London, UK, ISBN-10: 0124735401, pp: 674.

Marschner, P., 2012. Marschner's Mineral Nutrition of Higher Plants. 3rd Edn., Academic Press, Waltham, USA, ISBN-10: 9780123849052 , pp: 651.
Mayer, A.M. and R.C. Staples, 2002. Laccase: new functions for an old enzyme. Phytochemistry, 60: 551-565. DOI: 10.1016/S0031-9422(02)00171-1

Mohd Tayeb, D. and A.B. Hamdan, 1999. Relation of fertilizer nutrient to Ganoderma. Proceedings of the 1999 Palm Oil Research Institute of Malaysia (PORIM) International Palm Oil Congress, Emerging Technologies and Opportunities in the Next Millennium, Feb. 1-6, Istana Hotel, Kuala Lumpur, Malaysia, pp: 422-452.

Mohd Tayeb, D., A.S. Idris and H. Mohd Haniff, 2003. Reduction of Ganoderma infection I oil palm through balanced fertilizer in peat. Proceedings of the Agricultural Conference, Malaysian Palm Oil Board International Palm Oil Congress (PIPOC) 2003, Palm Oil, the Power-house for the Global Oils and Fats Economy, Aug. 24-24, Putrajaya Marriott Hotel, Malaysia, pp: 193-219.

Mortvedt, J.J, M.H. Fleischfresser, K.C. Berger and H.M. Darling, 1961. The relation of soluble manganese to the incidence of common scab in potatoes. Am. Potato J., 38: 95-100. DOI: 10.1007/BF02861972

Mortvedt, J.J., K.C. Berger and H.M. Darling, 1963. Effect of manganese and copper on the growth of Streptomyces scabies and the incidence of potato scab. Am. Potato J., 40: 96-102. DOI: 10.1007/BF02862727

Munevar, M.F., 2001. Fertilization of oil palm to obtain high yields. Palmas, 22: 9-17.

Naher, L., S.G. Tan, Y. Umi Kalsom, C.L. Ho and S. Siddiquee, 2012. Activities of chitinase enzymes in oil palm (Elaeis guineensis Jacq.) in interactions with pathogenic and non-pathogenic fungi. Plant Omics. J., 5: 333-336.

Nur Sabrina, A.A., M. Sariah and A.R. Zaharah, 2012. Suppression of basal stem rot progress in oil palm (Elaeis guineensis) after copper and calcium supplementation. Pertanika J. Tropical Agric. Sci., 35: $13-24$.

Pilotti, C.A., 2005. Stem rot of oil palm caused by Ganoderma boninense: Pathogen biology and epidemiology. Mycopathologia, 159: 129-137. DOI: 10.1007/s11046-004-4435-3

Ranade-Malvi, U., 2011. Interaction of micronutrients with major nutrients with special reference to potassium. Karnataka J. Agric. Sci., 24: 106-109.

Robson, A.D., R.D. Hartley and S.C. Jarvis, 1981. Effect of copper deficiency on phenolic and other constituents of wheat cell walls. New Phytologist, 89: 361-371. DOI: $10.1111 /$ j.14698137.1981.tb02317.x 
Sariah, M., M.Z. Hussin, R.N.G. Miller and M. Holderness, 1994. Pathogenicity of Ganoderma boninense tested by inoculation of oil palm seedlings. Plant Pathol., 43: 507-510. DOI: 10.1111/j.1365-3059.1994.tb01584.x

Sariah, M. and H. Zakaria, 2000. The Use of Soil Amendments for the Control of Basal Stem Rot in Oil Palm Seedlings. In: Ganoderma Disease of Perennial Crops, Flood, J., P.D. Bridge and M. Holderness (Eds.)., CABI Publishing, UK, ISBN-10: 9780851993881, pp: 89-112.

Shamala, S., 2005. Performance of Trichoderma harzianum Rifai as a Biological Control Agent for Basal Stem Rot of Oil Palm (Elaeis guineensis Jacq.) Caused by Ganoderma Boninense Pat. Unpublished Dissertation in Partial Fulfilment of the Requirements for the Degree of Master of Science. 1st Edn., Faculty of Science, University Putra Malaysia, Serdang, Selangor Malaysia, pp: 182.

Shamala, S., M. Sariah, A.S. Idris and O. Radziah, 2011. Symbiotic interaction of endophytic bacteria with arbuscular mycorrhizal fungi and its antagonistic effect on Ganoderma boninense. J. Microbiol., 49: 551-557. DOI: 10.1007/s12275-011-0489-3

Shimomura, T., 1982. Effect of boron on the formation of local lesions and accumulation of callose in French bean and Samsun NN tobacco leaves inoculated with tobacco mosaic virus. Physiol. Plant Pathol., 20: 257-261. DOI: 10.1016/00484059(82)90050-9

Siddiquee, S., Y. Umi Kalsom, K. Hossain and S. Jahan, 2009. In vitro studies on the potential Trichoderma harzianum for antagonistic properties against Ganoderma boninense. J. Food Agric. Environ., 7: 970-976.

Singh, G., 1991. Ganoderma-the scourge of oil palm in coastal areas. Planter, 67: 421-444.

Stangoulis, J.C.R. and R.D. Graham, 2007. Boron and Plant Disease. In: Mineral Nutrition and Plant Disease, Datnoff, L.E., W.H. Elmer and D.M. Huber (Eds.)., APS Press St Paul, Minnesota, USA, ISBN10: 978-0-89054-346-7, pp: 207-214.
Susanto, A., P.S. Sudharto and R.Y. Purba, 2005. Enhancing biological control of basal stem rot disease (Ganoderma boninense) in oil palm plantations. Mycopathologia, 159: 153-157. DOI: 10.1007/s11046-004-4438-0

Susanto, A., 2009. Basal stem rot in Indonesia-biology, economic importance, epidemiology, detection and control. Proceedings of the MPOB-IOPRI International Workshop on Awareness, Detection and Control of Oil Palm Devastating Diseases, Nov. 6-6, Kuala Lumpur Convention Centre, Kuala Lumpur Malaysia, pp: 18-18.

Tengoua, F.F. and C. Bakoume, 2005. Basal stem rot and vascular wilt, two threats for oil palm sector in Cameroon. Planter, 81: 97-105.

Tengoua, F.F., 2005. Report of phytosanitary inspection in Cameroon Development Corporation (CDC) mungo and mondoni palm estates.

Thompson, I.A. and D.M. Huber, 2007. Manganese and Plant Disease. In: Mineral Nutrition and Plant Disease, Datnoff, L.E., W.H. Elmer and D.M. Huber (Eds.)., APS Press, St Paul, Minnesota, USA, ISBN10: 978-0-89054-346-7, pp: 139-153.

Turner, P.D. and R.A. Gillbanks, 2003. Oil Palm Cultivation and Management. 1st Edn., Incorporated Society of Planters, Kuala Lumpur, Malaysia, ISBN10: 9679949443, pp: 633.

Utomo, C., S. Werner, F. Niepold and H.B. Deising, 2005. Identification of Ganoderma, the causal agent of basal stem rot disease in oil palm using a molecular method. Mycopathologia, 159: 159-170. DOI: $10.1007 / \mathrm{s} 11046-004-4439-\mathrm{z}$

Veresoglou, S.D., E.K. Barto, G. Menexes and M.C. Rillig, 2013. Fertilization affects the severity of disease caused by fungal plant pathogen. Plant Pathol., 62: 961-969. DOI: 10.1111/ppa.12014

Wan, H.H., 2007. Ganoderma disease of oil palm in Sabah. Planter, 83: 299-313. 